\title{
Multiple deformation episodes at Myra Falls volcanic-hosted massive sulfide camp, central Vancouver Island, British Columbia, Canada
}

\author{
Sarah Jones, Ron Berry, and Briony Sinclair
}

\begin{abstract}
A detailed deformation history for central Vancouver Island was determined at Myra Falls volcanic-hosted massive sulfide camp with early ductile deformation overprinted by several distinct episodes of brittle deformation. Brittle structures were subdivided into separate groups based on their morphology, geometry, kinematics, and crosscutting relations. The central location of this study provides a link between previous deformation studies in northem and southem Vancouver Island. Late Paleozoic northeast-southwest compression $\left(\mathrm{D}_{\mathrm{I}}\right)$ produced open upright folds with variably developed north-northwest-striking axial planar cleavage zones (SI) and subhorizontal stretching lineations (LI) subparallel to FI fold axes. Renewed northeast-southwest compression during the collision of Wrangellia and North America produced a second foliation (S2) in localized shear zones, slightly oblique to the dominant SI foliation. These twO events are recorded throughout Vancouver Island wherever the basement is exposed. Mid-Cretaceous northeastsouthwest compression during $\mathrm{D}_{3}$ produced early Steep conjugate strike-slip faults $\left(\mathrm{D}_{3 \mathrm{a}}\right)$, overprinted by northeast- and southwest-dipping thrust faults and bedding-parallel shears $\left(\mathrm{D}_{3 \mathrm{~b}}\right) . \mathrm{D}_{3}$ structures have been previously recognized in northem Vancouver Island but not as far south as Myra Falls. North-south extension $\left(\mathrm{D}_{4}\right)$ produced east, north, and east-southeast-striking normal faults. These faults consistently crosscut earlier $\mathrm{D}_{\mathrm{I}}-\mathrm{D}_{3}$ structures and reactivate steep $\mathrm{D}_{3 \mathrm{a}}$ faults. Normal faulting is correlated with the development of the Upper Cretaceous Nanaimo Basin, but no faults of this age have previous been reported from onshore studies. The youngest structures at Myra Falls are large northweststriking, northeast-dipping tbrust faults and steep west- to west-northwest-striking sinistral strike-slip faults formed during the $\mathrm{D}_{\mathrm{S}}$ event. These faults are gouge-rich, wavy anastomosing structures, with cleaved wall-rock zones up to several metres wide. The $\mathrm{D}_{\mathrm{S}}$ faults are correlated with Eocene deformation caused by the accretion of the Pacific Rim and Crescent Terranes along the southwestern margin of Vancouver Island. Myra Falls is the northemmost location to have been reported, at which the structures formed as part of the Cowichan fold and tbrust belt.
\end{abstract}

Résumé : L'historique détaillé de la déformation du centre de l'île de Vancouver a été etabli au camp de sulfures massifs volcanogenes de Myra Falls, là où une déformation ductile precoce a été surimprime par plusieurs episodes distincts de déformation cassante. Les structures cassantes ont été subdivisees en groupes distincts selon leur morphologie, leur géométrie, leur cinematique et leuIs relations de recoupement. La localisation centrale de cette étude foumit un lien entre les etudes de déformation anterieures dans le nord et le sud de l'île de Vancouver. La compression nord-estsud-ouest ( $\mathrm{D}_{\mathrm{I}}$ ) au Paléozoïque tardif a produit des plis droits ouverts avec des zones de clivage planaire axial (SI) de direction nord-noId-ouest, à developpement variable, et des lineations d'etirement sub-horizontales (L,) sub-paralleles aux axes de plis FI. Lors de la collision entre Wrangellia et l'Amerique du Nord, une nouvelle compression nord-estsud-ouest a produit une seconde foliation (S2), légèrement oblique à la foliation dominante SI' dans des zones de cisaillement localisees. L'evidence de ces deux événements est visible à travers toute l'île de Vancouver, là où affleure le socle. Au Crétacé moyen, la compression nord-est - sud-ouest durant $\mathrm{D}_{3}$ a produit des failles de decrochement conjuguées precoces et abruptes $\left(\mathrm{D}_{3 \mathrm{a}}\right)$, lesquelles sont surimprimees par des failles de chevauchement à pendage nord-est et sud-ouest et des cisaillements paralleles au litage $\left(\mathrm{D}_{3 b}\right)$. Des structures $\mathrm{D}_{3}$ ont été reconnues anterieurement dans le nord de l'île de Vancouver mais pas en des endroits aussi au sud que Myra Falls. Une extension nord-sud $\mathrm{D}_{4}$ a produit des failles normales est, nord et est-sud-est. Ces failles recoupent les structures DI- $\mathrm{D}_{3}$ anterieures de maniere constante et elles reactivent des failles abruptes $\mathrm{D}_{3 \mathrm{a}}$. Le developpement de failles normales est corrélé au développement de la ceinture Nanaimo (Crétacé superieur) mais aucune faille de cet äge n'a été rapportee lors d'etudes terrestres. Les plus jeunes structures à Myra Falls sont de grandes failles de chevauchement à direction nord-ouest et à pendage nord-est et des failles de decrochement senestres abruptes de direction ouest à ouest-nord-ouest qui se sont formees durant

Received 8 August 2005. Accepted 19 April 2006. Published on the NRC Research Press Web site at http://cjes.nrc.ca on 24 January 2007.

Paper handled by Associate Editor K. AnsdelI.

S. Jones,I,2 R. Berry, and B. Sinclair. Centre for are Deposit Research, University of Tasmania, Private Bag 79, Hobart, Tasmania, 7001, Australia.

ICorresponding author (e-mail: sarah.jones@rsgglobal.com).

2Present address: RSG Global, P.O. Box 1671, West Perth, WA6872, Australia. 
l'événement $\mathrm{D}_{\mathrm{S}}$. Ces failles sont des structures fortement rainurees, ondulantes et anastomosees, avec des zones d'une (argeur de plusieurs metres où l'eponte superieure est bien clivee. Les failles Os sont corrélées avec la déformation à l'Éocène causee par !'accretion des terranes Pacific Rim et Crescent le long de la bordure sud-ouest de l'île de Vancouver. Myra Falls est J'emplacement le plus au nord où ont été rapportees des structures forrnees en tant que partie du pli et de la ceinture de chevauchement Cowichan.

[Traduit par la Redactioo]

\section{Introduction}

Regional deformation studies on Vancouver Island (e.g., MulJer 1980; Massey 1992; Nixon et al. 1994; Mackie 2002) have identified multiple deformation events that reflect the complex tectonic history of the island. For example, Massey (J 992) describes five separate deformation events in the southem and south-central parts of Vancouver Island, ineluding pre-Triassic ductile deformation, mid to Late Triassie crustal dilation, Early to mid Jurassie warping, post-mid to pre-Late Cretaceous faulting, Late Cretaceous to Eocene northweststriking faults, and post-Eocene faulting. Nixon et al. (1994, 1995) also describe multiple deformation events in the northem part of Vancouver IsJand: phase I post-Early Jurassie to pre-Cretaceous folding, phase 2 post-mid to (?)pre-Late Cretaceous faulting, and phase 3 post-Upper Cretaceous extension. However, no attempt has been made to correlate this history across the whole of Vancouver Island.

Previous work has noted the dominance of faulting in the deformation history, but this study is the first that attempts a solution to the complex fault history defined by fault striation data. The previous studies infer fault history by considering the regionaloffsets on faults. The latter method has limited ability to handle examples of multiple reactivation, which are common in the area. The complexity of fault movement in the Myra Falls area is such that it can only be resolved by very elose observation of the style associated with each generation of movement (cf. Liesa and Lisle 2004). In the context of this study, earlY faults have chlorite, quartz, and epidote slickenfibres, and have associated narrow eleavage zones typical of relatively high temperatures, while the Jater faults are brittle with no new minerals crystallized suggesting relatively lower temperatures. A detailed assessment of these changing styles combined with the overprinting relationships has resolved four generations of faulting in the Myra Falls area. The analysis of this structurally complex area is used to link structuraJ studies in the north and south of the island to improve our understanding of the distribution of deformation events. The regional distribution of deformation events is then linked to the tectonic history of the island and used to develop a regional tectonostratigraphic framework for the area.

\section{Tectonic setting}

Myra Falls volcanic-hosted massive sulphide (VHMS) camp is located in Strathcona Provincial Park in central Vancouver Island, British Columbia, Canada (Fig. I) and is hosted by the Paleozoic Sicker Group, which forms the basement rocks of Vancouver Island. The Sicker Group is the basement of the WrangeHia Terrane and is exposed in a number of anticlinal zones ineluding the Buttle Lake, Cowichan, Nanoose, and West Coast uplifts (Muller 1980).

In the Buttle Lake area, Juras (1987) subdivided the $4000 \mathrm{~m}$ thick Sicker Group into four formations: the Price, Myra, Thelwood, and Flower Ridge formations (Figs. 2, 3). The $\mathrm{Cu}-\mathrm{Pb}-\mathrm{Zn}$ deposits at Myra Falls are hosted in the Myra Formation (Juras and Pearson 1990a, 1990b; Robinson et al. 1996; Barrett and Sherlock J996; Sinelair et al. 2000). The sequence at Myra Falls is characterized by greenschist-facies metamorphism, with local amphibolite-facies contact aureoles developed adjacent to Jurassie Island Suite intrusions (Juras 1987; Greenwood et al. 1991).

A large unconformity separates the Sicker Group from the limestones of the Permian Buttle Lake Group (Jeffery 1967; Brandon et al. 1986; Juras 1987; Massey 1992). The Iimestones are conformably overlain by the Vancouver Group, which comprises extensive volcanic rocks (Karmutsen Formation), limestone, flaggy argillite and quartzite of Late Triassie age (Yorath et al. 1999). The Vancouver Group is overlain by the Early Jurassie Bonanza Group, which ineludes calc-alkaline volcanic rocks and minor interbedded sediments (Bonanza Volcanics). The Bonanza Group is coeval with quartz diorite, granodiorite, and quartz monzonite of the Island Intrusive Suite (Gunning 1931; Dawson et al. 1991 ; Gordey et al. 1991; Yorath et al. 1999). The Late Cretaceous Nanaimo Group and younger rocks on Vancouver Island were deposited after the collision of Wrangellia with North America (Gabrielse and Yorath 1991).

Some of the deformation of Vancouver Island resulted from the amalgamation of Wrangellia and Alexander terranes to form the Insular Belt, and from the collision of Wrangellia with the ancient margin of the North American continent (Monger et al. 1985; Gabrielse 1991). An early phase of folding in the Paleozoic rocks predated the collision of Wrangellia and North America. A second phase of folding, usually correlated with the collision events, resulted in the regional-scale warping and formation of the major northwesttrending antielinal structures, such as the Buttle Lake and Cowichan uplifts in southem and central Vancouver Island (Muller 1980; Massey 1992) and the Victoria Arch in the north (Nixon et al. 1994).

In northem Vancouver Island, amid Cretaceous northerly directed compressional event produced steep strike-slip faults and bedding-parallel shears that deformed the mid Cretaceous Coal Harbour Group but did not affect the Late Cretaceous Nanaimo Group (Nixon et al. 1994). This event has yet to be documented in southem Vancouver Island, possibly because of the lack of mid-Cretaceous correlates of the Coal Harbour Group in the southem area. The Late Cretaceous to 
Fig. 1. Location and tectonic setting of Myra Falls VHMS camp, Vancouver IsJand, modified from Muller (I980) and Yorath et aJ. (I999).

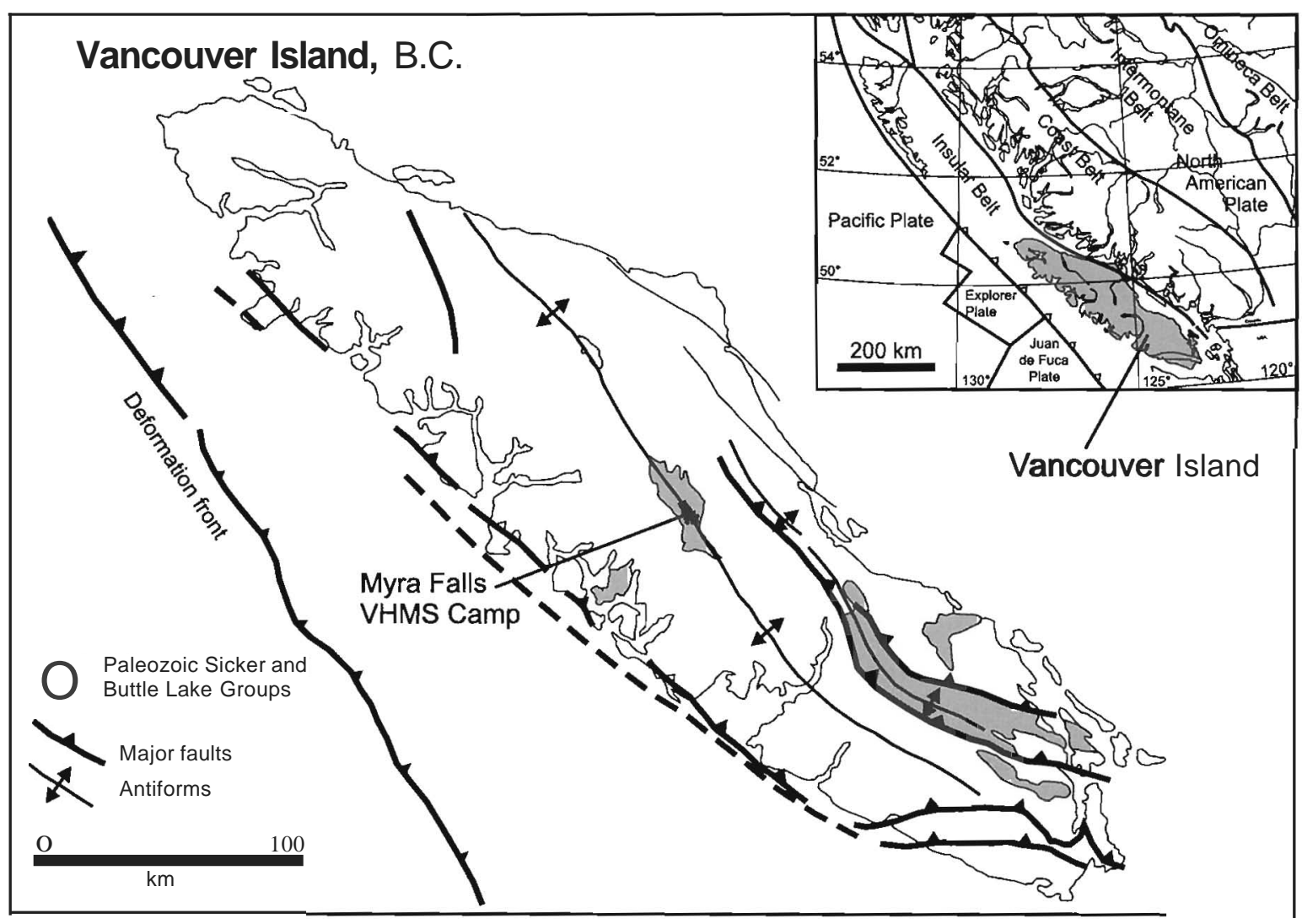

Eocene collision and accretion of the Pacific Rim and Crescent terranes beneath Wrangellia along the southwestem margin of Vancouver Island (Fig. 4) resulted in the folding and faulting of the Late Cretaceous Nanaimo Group sediments to form the northwest-verging Cowichan fold and thrust belt (England and Calon 1991; Massey 1992) but this event has not been recognized in northem Vancouver Island.

Today, Vancouver Island lies about $200 \mathrm{~km}$ east of the active Juan de Fuca spreading ridge. The Juan de Fuca plate is being subducted beneath the North American plate, forming a new accretionary complex (Gabrielse and Yorath 1991).

\section{Methods}

Structural measurements were collected at the Myra Falls VHMS camp over four field seasons, from underground in the HW, Battle, Lynx, and Price mines, and from surface measurements in the Lynx and Myra open-cut, Price hillside, and Westmin road cuttings. The structural data were then compiled into three main domains: the Battte, HW, and Price domains. Approximately 1000 fault planes and striations were measured, along with foliations, fold axes, and mineral lineations. Structural interpretations on drill hole sections were constructed from detailed drill core logging. The location, orientation, and displacement sense of some of the larger structures, such as the Lynx-Phillips, Myra-Price, and North fault zones, are partly based on previous mapping and interpretations by company geologists. The orientation and location of other structures, such tbe Flat Fault (or Battle-
Main Fault) and tbe East-Main Fault, are based on a combination of company data, isopach maps, and underground measurements collected during the study. True north is used throughout the paper, however, some diagrams also show the local mine grid (mine north is $+48^{\circ}$ from true north).

\section{Separation of brittle deformation events}

A range of fault styles with variable orientations and kinematics were identified at Myra Falls, making it difflCUlt to determine a clear deformation sequence. The faults were separated into groups based on the fault geometry, morphology and kinematics. The criteria used to sort the faults included (1) fault orientation; (2) displacement sense; (3) style of kinematic indicators (e.g., fibre or groove size, fibre mineralogy); (4) geometry, (e.g., wavy, anastomosing er planar style); (5) presence of fault gouge; (6) presence of cleaved zones along the fault margins; and (7) associated vein types.

Faults ranged in style from planar, gouge-free faults with quartz-epidote-cblorite fibres, to wavy anastomosing faults with abundant gouge and rare fibres. The relative timing of fault phases was determined by crosscutting relations observed in surface and underground exposures. Particular attention was paid to the overprinting relations of striations on fault surfaces, including fibre overgrowths and grooves across older fibres.

The sense of displacement on fault surfaces was deterrnined by using criteria summarized by Petit (1987). At Myra Falls, the most reliable criterion was fibre veins attached to the 
Fig. 2. Stratigraphie eolumn for Vaneouver lsland, modified from England and Calon (1991), Massey (1992) and Yorath et al. (J 999).

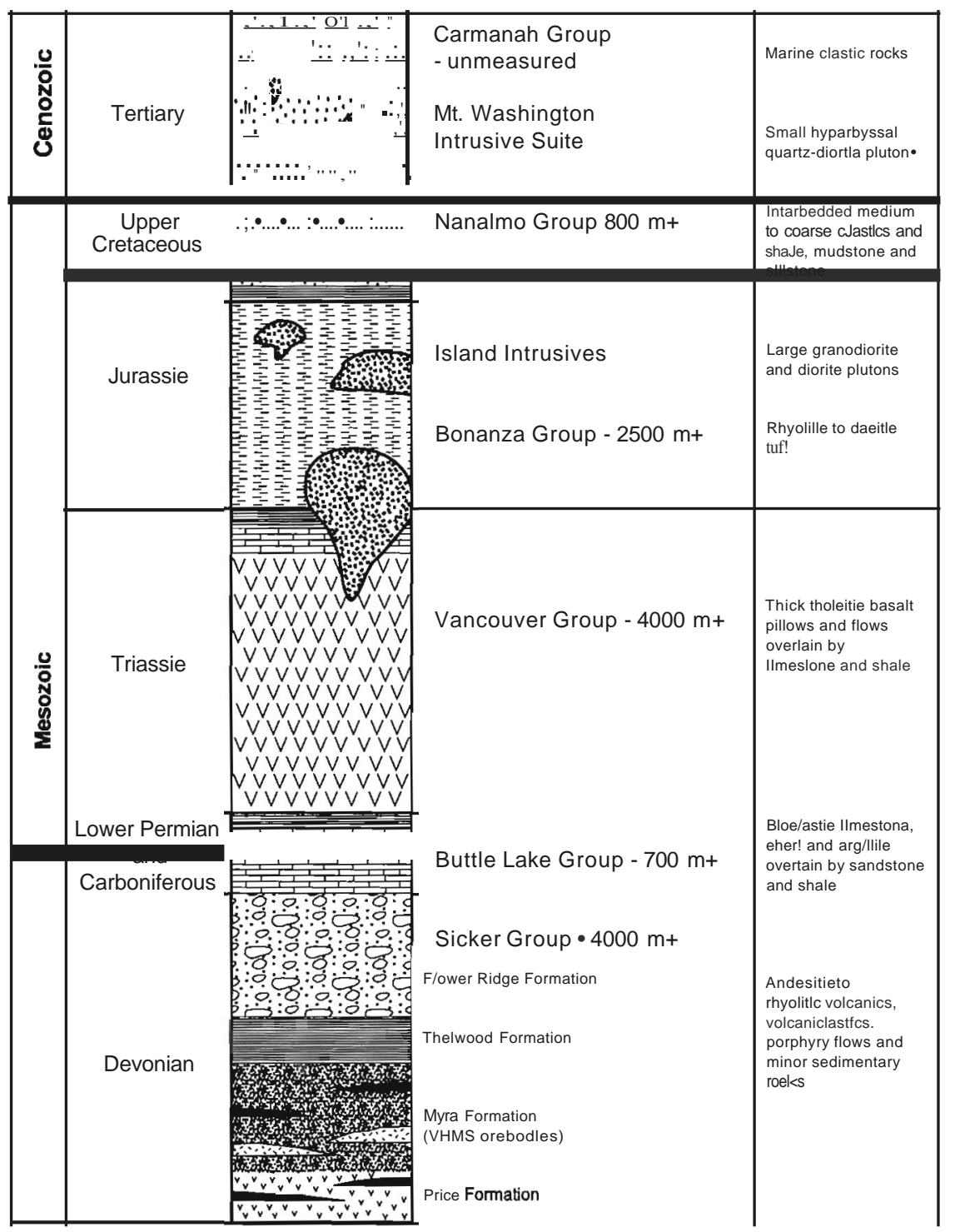

back of ledges on the fault surfaee. However, sliekenfibres were absent on many gouge-rieh faults, whieh are eommonly eharaeterized by fine grooves instead. The sense of displacement on these faults was determined by fault drag of foliation and (or) bedding, shadowing of grooves aeross an undulating fault surfaee, the presenee of gouge in front of ledges, and offsets of bedding and mafie dykes.

\section{Paleostress analysis}

Paleostress analysis was undertaken on the fault groups. Fault data was divided into five main areas or domains eomprising the Battle mine, Lynx mine and open-cut, HW mine, Westmin Road eutting above Buttle Lake, and the Priee area. Striations from eaeh fault group were tested for eompatibility with a uniform stress using the method of Eteheeopar et aI. (1981). In eaeh ease, $85 \%$ of striations are eompatible with a single regional stress state for these diserete loeations. No further subdivision of the deformation phases was possible using this method.

\section{Deformation history of Myra Falls}

The volcanie sequenee at Myra Falls has undergone multiple deformation events (Walker 1985; Juras 1987; Juras and Pearson 19900). A eontour map of the top of the Priee Andesite (footwaII to the VHMS deposits) (Fig. 5) highlights the major struetures affeeting the sequenee, with a [arge topographie high south and west of the mines, representing the hinge zone of the Myra Antieline (Fig. 6). Two large fault zones, the Myra-Priee Fault Zone in the southeast and the Lynx-Phillips Fault Zone in the northwest, offset the anticline. A large topographie low in the north eastem part of the property is a result of down-throw along the North Fault. Smaller topographie lows, or basins, oeeur beneath 
Fig. 3. Geology of the Myra Falls area, modified from Geological Survey of Canada information circular, 1995-1997.
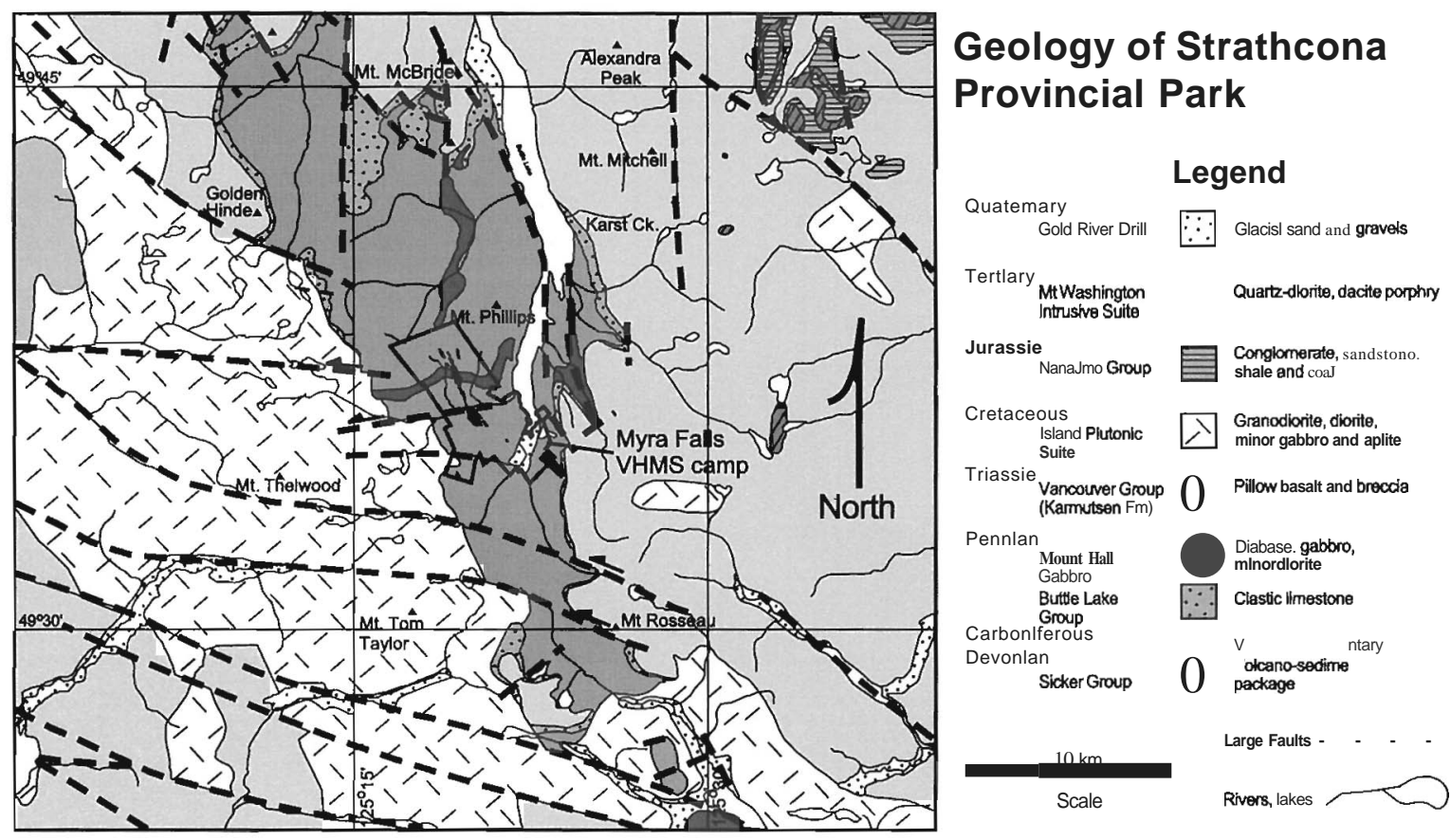

Fig. 4. Schematic cross-section through the southwestern part of Vancouver Island, modified from Hyndman et al. (1990).

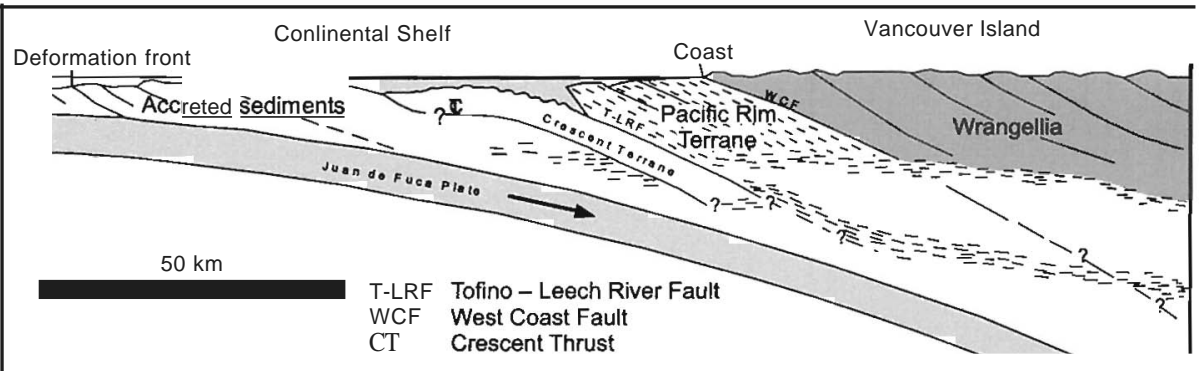

Fig. 5. Contour map of the top surface of the footwall lithology to Myra Falls VHMS deposits, the Price Andesite. Marked changes in the footwall contours highlight displacements along major structures. Areas with no drill hole information are blank.

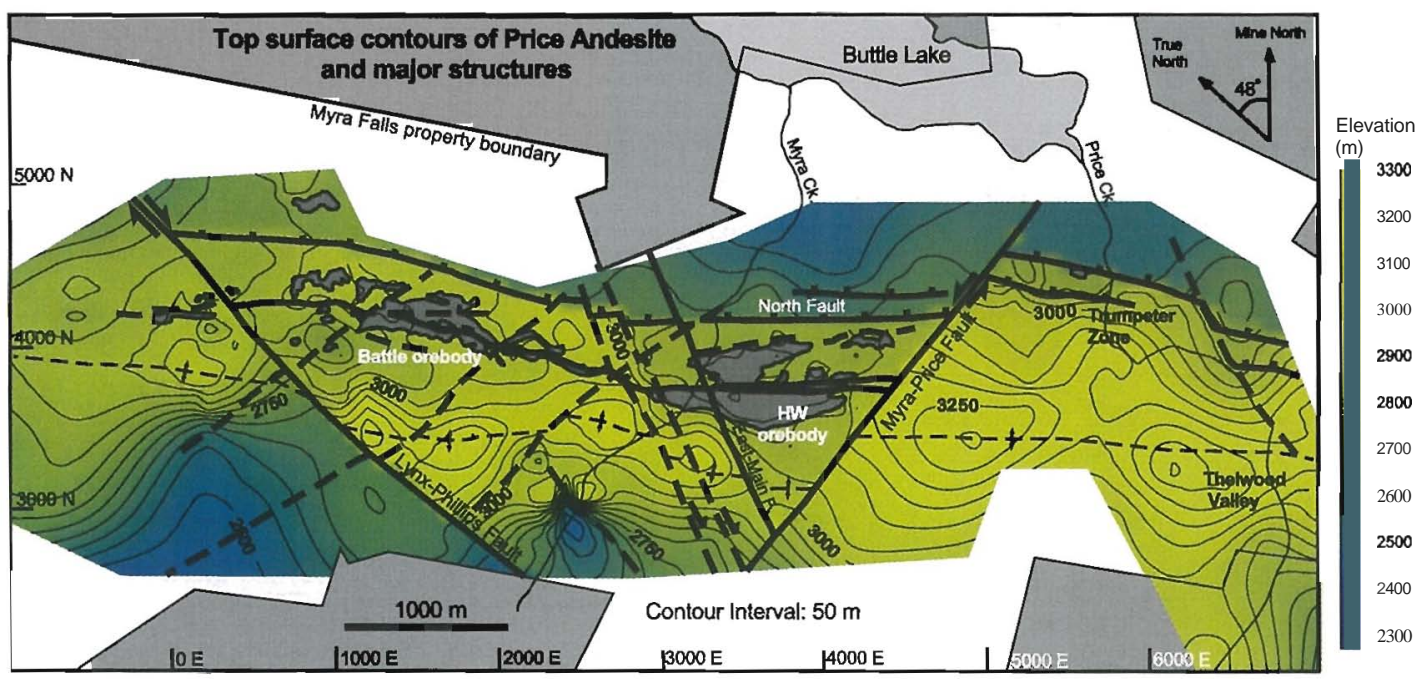


Fig. 6. Composite northeast-southwest-oriented schematic cross-section ( $3500 \mathrm{~m}$ east) illustrating the affect of D, folding on the volcano-sedimentary sequence at Myra Falls (modified after Pearson 1993).

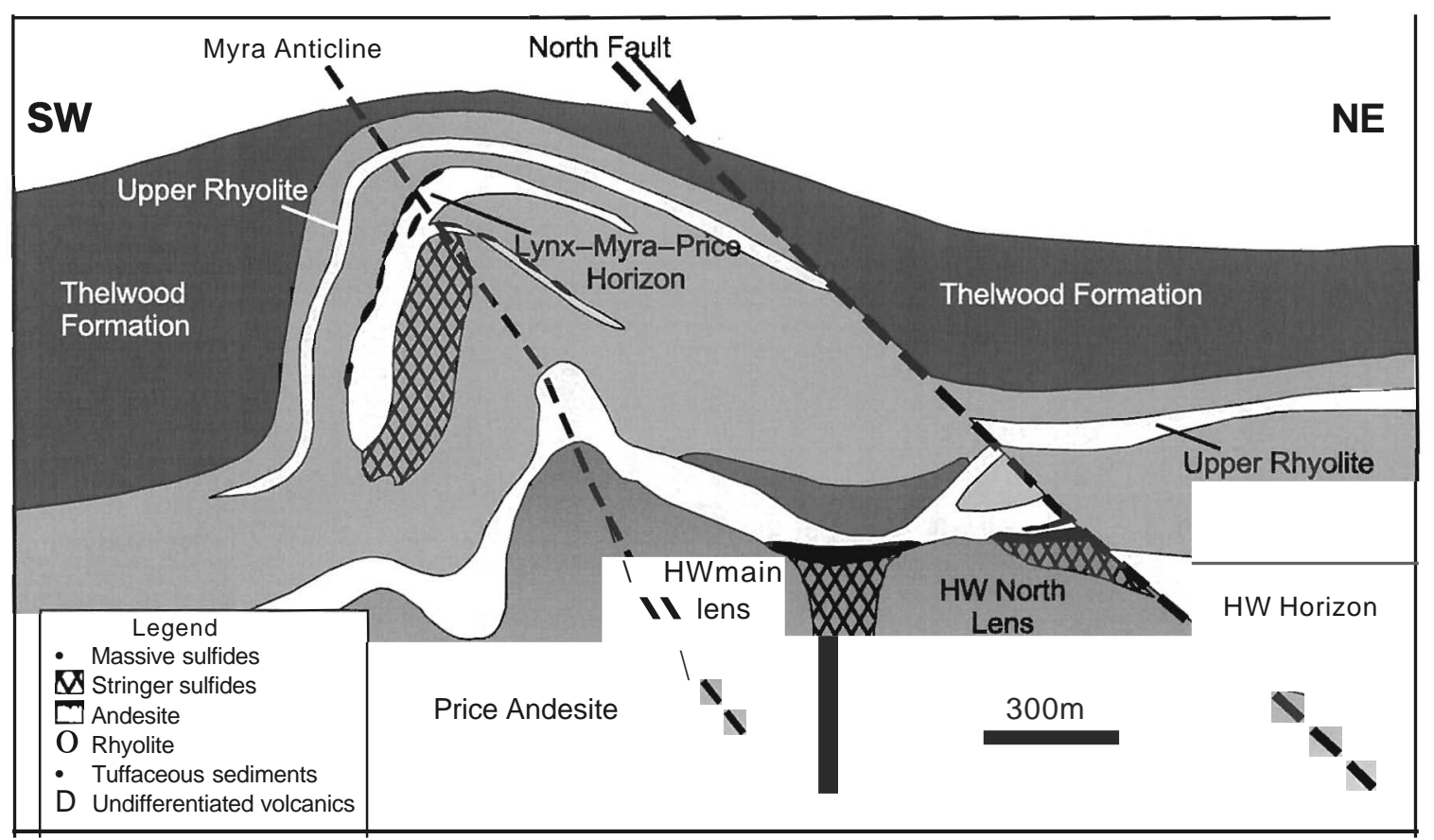

Fig. 7. Deformation sequence at Myra Falls.

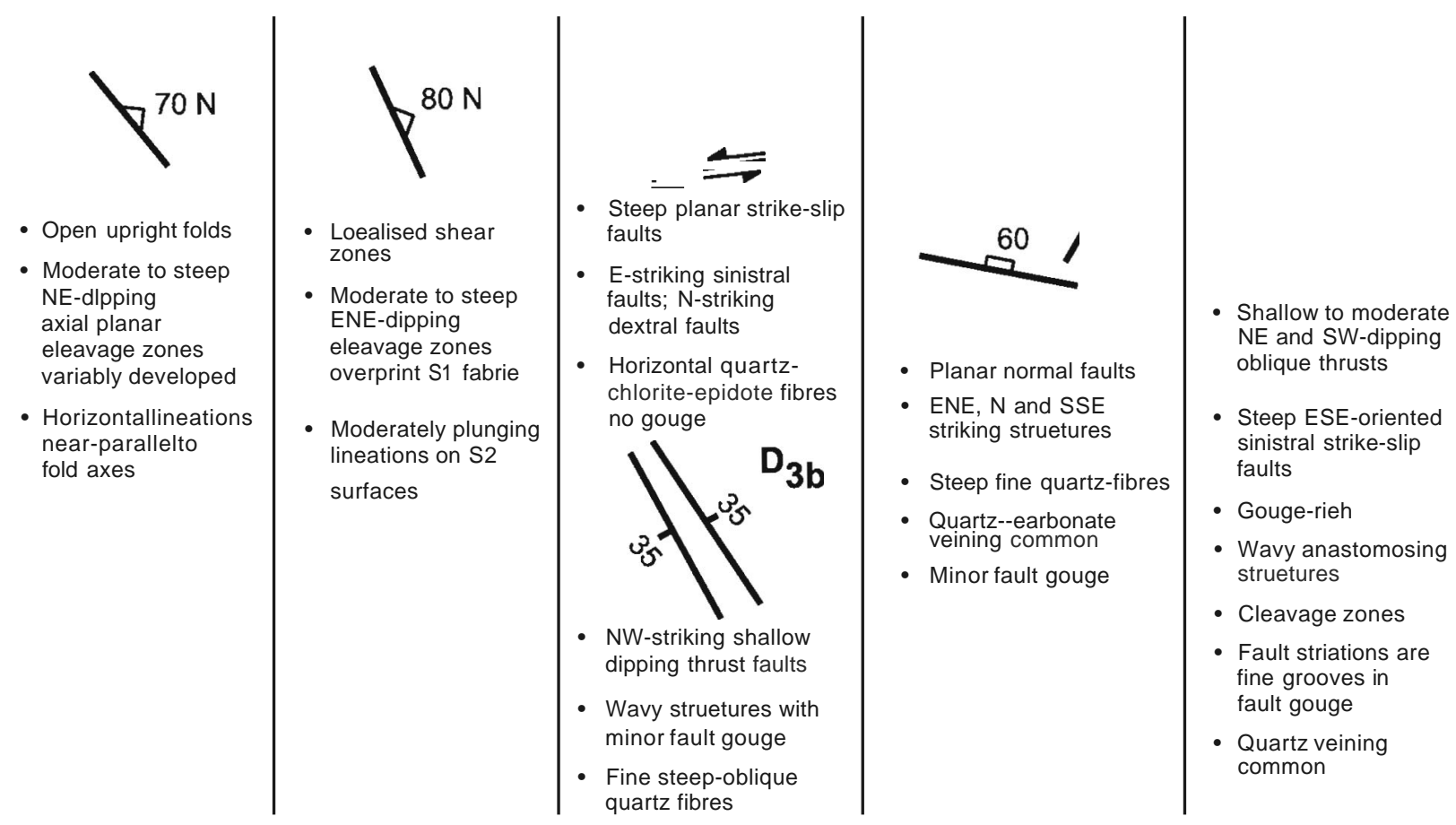

the HW orebody and west of the Battle orebody. These are interpreted as the original basins fonned eontemporaneously with the VHMS orebodies. Rapid ehanges in footwall elevation aeross these basins, and assoeiated stratigraphie thiekening, indieate the presenee of syndepositional growth faults (Juras 1987; Juras and Pearson 1990a; Pearson 1993; Jones 2002).

The four main fault groups reeognized at Myra Falls, are (1) steep planar eonjugate strike-slip faults with eoarse (2- 
Fig. 8. Map illustrating the reconstructed pre- $\mathrm{D}_{3}, \mathrm{~S}_{1}$, and $\mathrm{S} 2$ foliation pattern at Myra Falls.
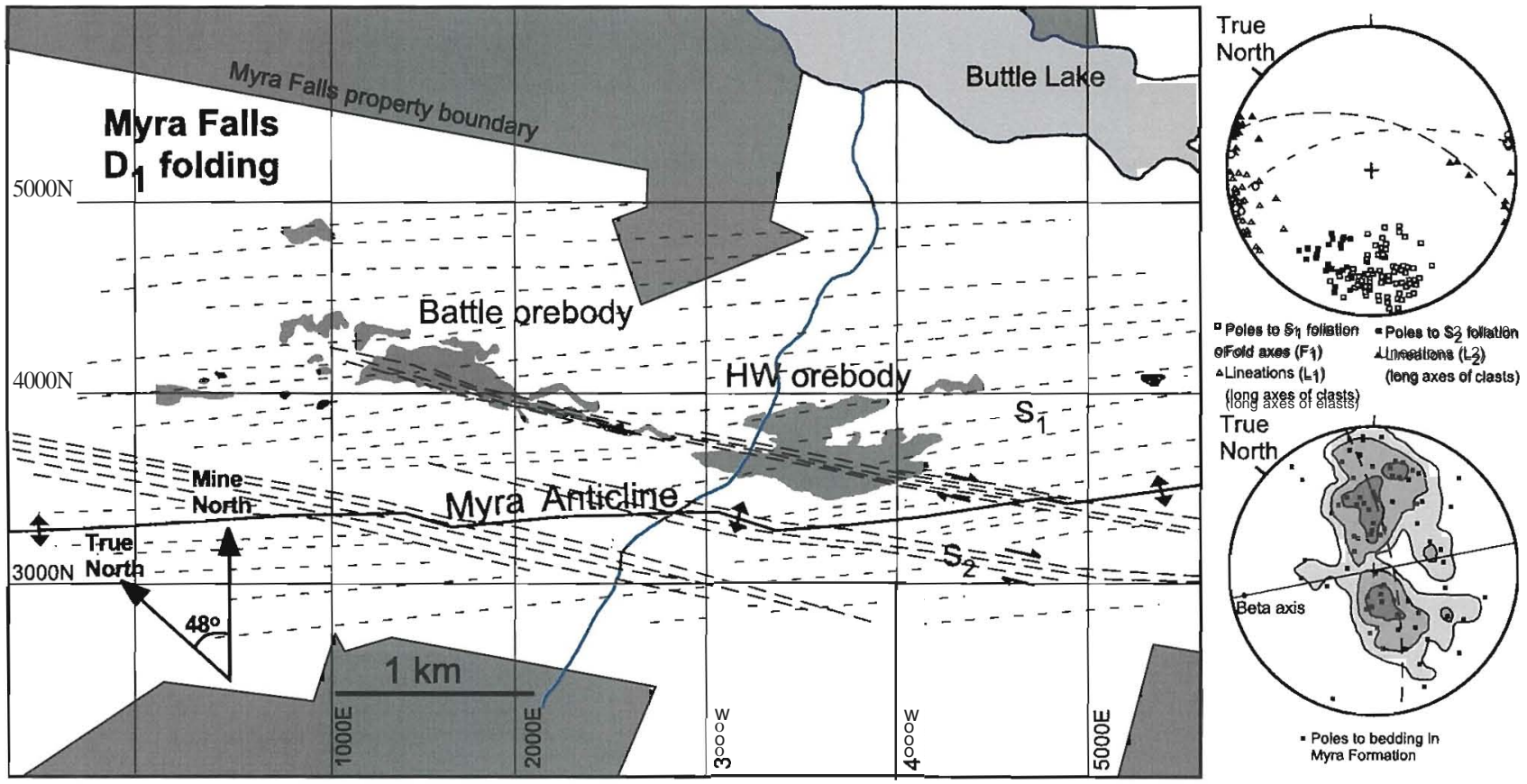

$5 \mathrm{~mm}$ ) shallowly plunging quartz-epidote-chlorite fibres; (2) shallow to moderately dipping, wavy anastomosing thrusts with zones of cleaved rock (2-10 $\mathrm{cm}$ wide) and minor gouge; (3) steep planar nonnal faults with fine quartz fibres; and (4) wavy anastomosing gouge-rich thrust faults and steep strike-slip faults.

The relative age of the four main groups of faults are detennined by erosseutting relations. Group 1 planar strike-slip faults with shallow coarse quartz-ehlorite-epidote fibres do not offset other faults and, therefore, are inferred to be the oldest fault group. The shallow-dipping thrust faults (group 2) crosscut the steep planar strike-slip faults and are in turn offset by steep planar nonnal faults (group 3). Gouge-rieh thrusts and steep strike-slip faults (group 4) crosscut all other fault groups and, therefore, represent the youngest fault group.

The defonnation history at Myra Falls (Fig. 7) is as follows:

- Syndepositional growth faults

- D) folding

- $\mathrm{D}_{2}$ loealized shear zones

- $\mathrm{D}_{3 \mathrm{a}}$ steep strike-slip faults (fault group I), crosscut by shallow-dipping $\mathrm{D}_{3 \mathrm{~b}}$ thrust faults (fault group 2)

- $\mathrm{D}_{4}$ planar nonnal faults (fault group 3)

- $\mathrm{D}_{\mathrm{S}}$ gouge-rieh thrust faults and steep strike-slip faults (fault group 4)

Growth faults (Early to Middle Devonian)

Syndepositional growth faults are assoeiated with basin fonnation sedimentation and are poody preserved. The growth faults are overprinted and destroyed by subsequent defonnation and direet measurement of these struetures was not possible. Instead their loeation and orientation was inferred from rapid ehanges in footwall elevation accompanied by stratigraphie thickening, marked facies variation and metal zonation in the
Devonian $\mathrm{Cu}-\mathrm{Pb}-\mathrm{Zn}$ orebodies (Sinelair 2000; Jones et al. 2000; Jones and Berry 2001).

D] folding (Middle Permian to pre-Middle Triassie)

Northeast-southwest eompression during $\mathrm{D}_{1}$ produeed northwest-trending folds with a variably developed northeastdipping axial planar cIeavage (SI) and subhorizontal to shallow nortbwest-plunging lineations. A major northwest-trending anticline extends through the upper Lynx-Myra-Priee orebodies and the hinge may have been loealized by strong serieite alteration around the VHMS orebodies (Fig. 5). The orientation of SI aeross the property, and the reeonstrueted pre- $\mathrm{D}_{3}$ position of the Myra Anticline, is shown in Fig. 8.

Photos and underground wall maps (Fig. 9) illustrate the typieal open upright fold style assoeiated with the $\mathrm{D}_{\mathrm{I}}$ event in folded ehert and siltstone immediately above the massive sulfides in the Battle and HW mines. The eaIculated fold axis (Fig. 9) is subparallel to the northwest-trending FI fold hinges and the long axes of stretehed elasts (LI)'

The SI foliation is defined by aligned muscovite and chlorite, reerystallized quartz, and wavy carbonaceous seams in pelites (Fig. 10). The eleavage typically occurs as a spaced fabric of muscovite seams that crosscut bedding at a high angle. Small quartz tails are common in strain shadows beside pyrite grains and detrital quartz grains are fractured and have undulose extinction. Planar fahries are dominant, but S-L fabries (planar dominant over linear fabrics) to L-S fabrics are loeally developed with the linear fabric defined by the lang axes of elasts.

Upright folding and associated fabries are observed throughout the Paleozoic rocks on Vancouver Island. Muller (1980) and Massey (1992) reported northwest-trending, southwestverging asymmetrical folds with a variably developed axial planar eleavage and subhorizontal Iineations in the Cowichan 
Fig. 9. (a) Folded chert and siltstone above massive sulfides, drive ST183A, BattJe Mine; (b) pen folds in chert immediately above massive sulfides in HW mine, 20 level; $(c, d)$ stereoplots of $\mathrm{D} \backslash$ and $\mathrm{D}_{2}$ structural elements, with data from HW and Battle mines; (e) underground wall maps from the HW and Battle mines illustrating the typical style of $\mathrm{D}_{1}$ folds that are offset by numerous faults.

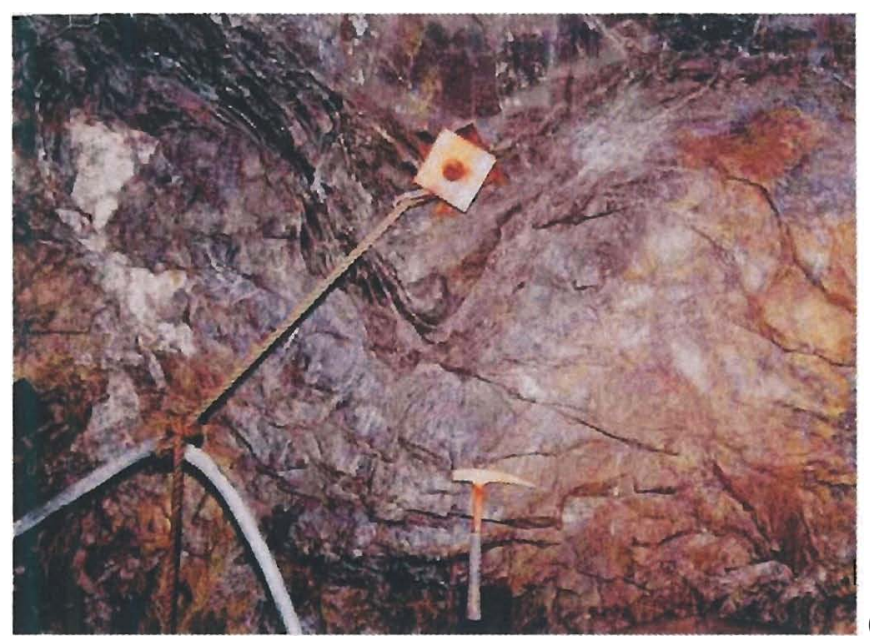

(a)

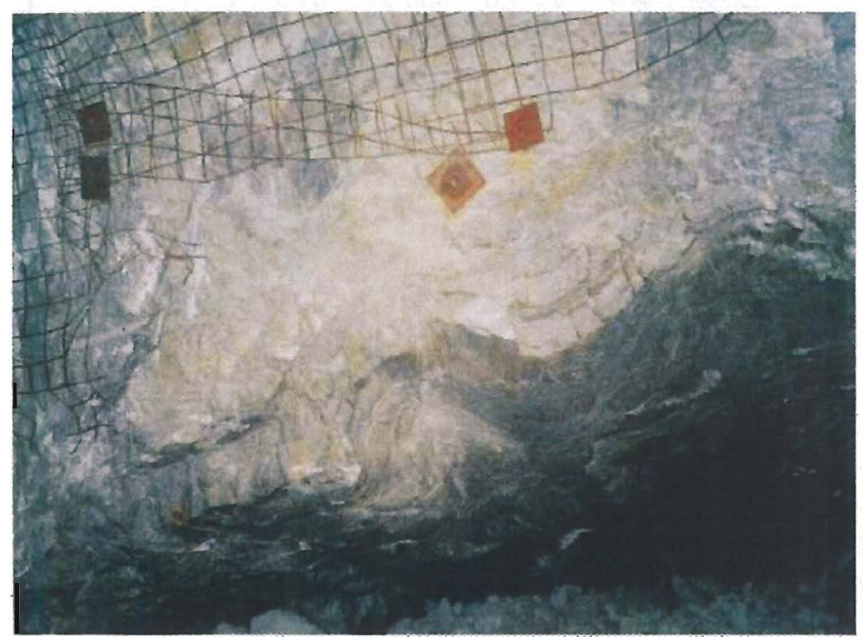

(b)
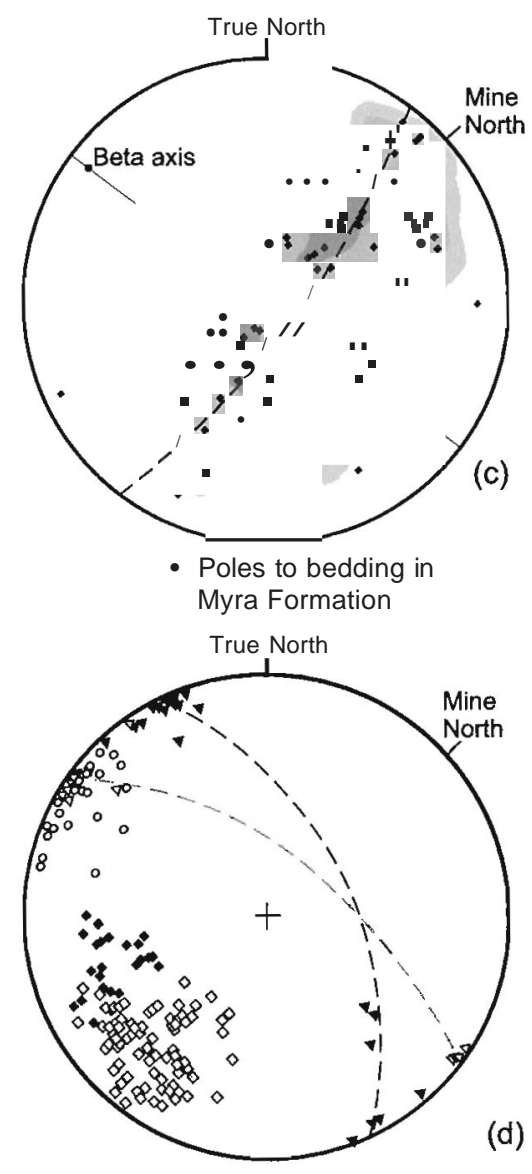

oPales to 51 follation Poles to 52 foliatlon

$\nabla$ Fold axes $\left(F_{1}\right) \quad \forall$ L1neations $\left(L_{2}\right)$

Lineations $\left(\mathrm{L}_{1}\right)$

(long axis of elasts)

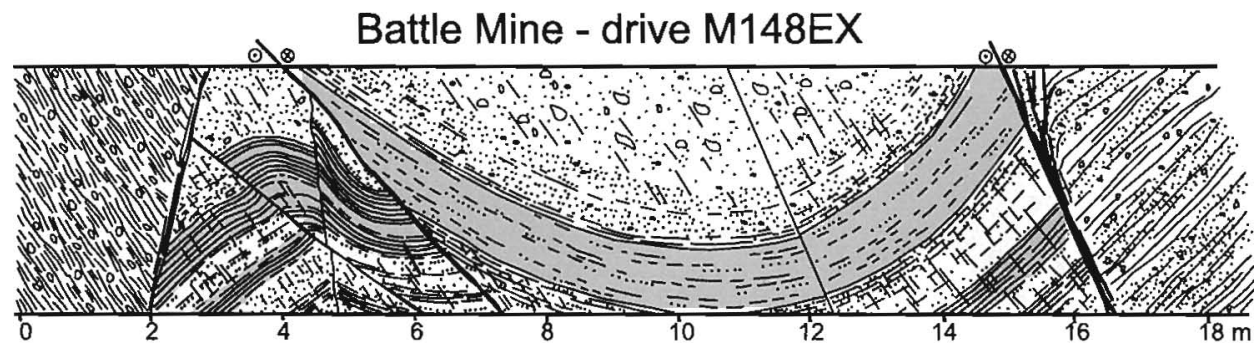

Battle Mine - drive ST183A
Legend

Strongly follated rhyolitic volcanlclastic

Deakly follated rhyolitic volcaniclastlc

Fine gralned rhyolitic

Bedded chert and sillstone

Massive 10 semimassive sulphides

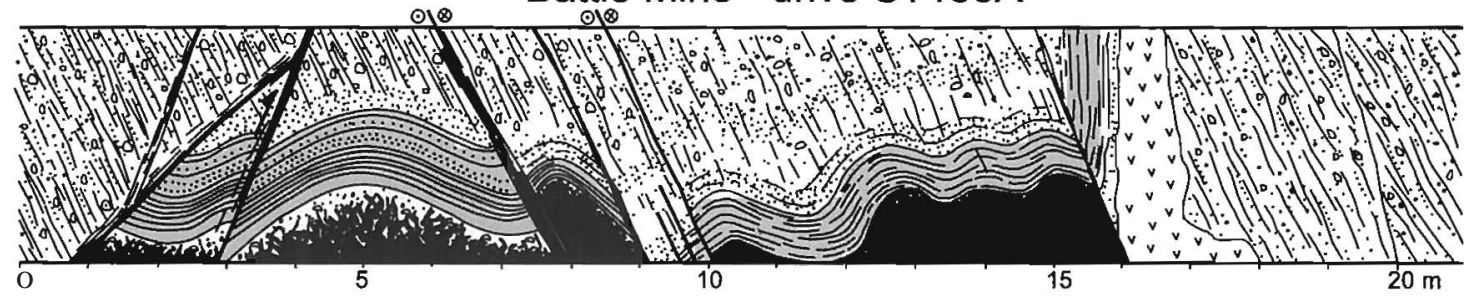

(e) 
Fig. 10. Microscale textures in rhyolitic volcaniclastic rocks at Myra Falls: (a) Carbonaceous-rich layers (bedding) is overprinted by fine wavy carbonaceous seams defining the SI fabric, plain polarized light (PPL) (sampIe SJ47, drillhole 23-493, 17.6m); (b) fractured detritaJ quartz grain showing undulose extinction, the SI fabric wraps around the grain, cross-polarized light (XPL) (sampie SJ90, drive S335A-D6, HW mine); (c) Extensional crenulation cleavage is weil developed in oriented siltstone sampie (sampie SBI9, drive 23-N350, HW mine), XPL; (d) Quartz tail growing in the pressure shadow of a pyrite grain, surrounded by strongly aligned muscovite, (sampie SJ90, drive S335A-D6, HW mine), XPL. Mineral abbreviations: py, pyrite; m, muscovite; q, quartz.
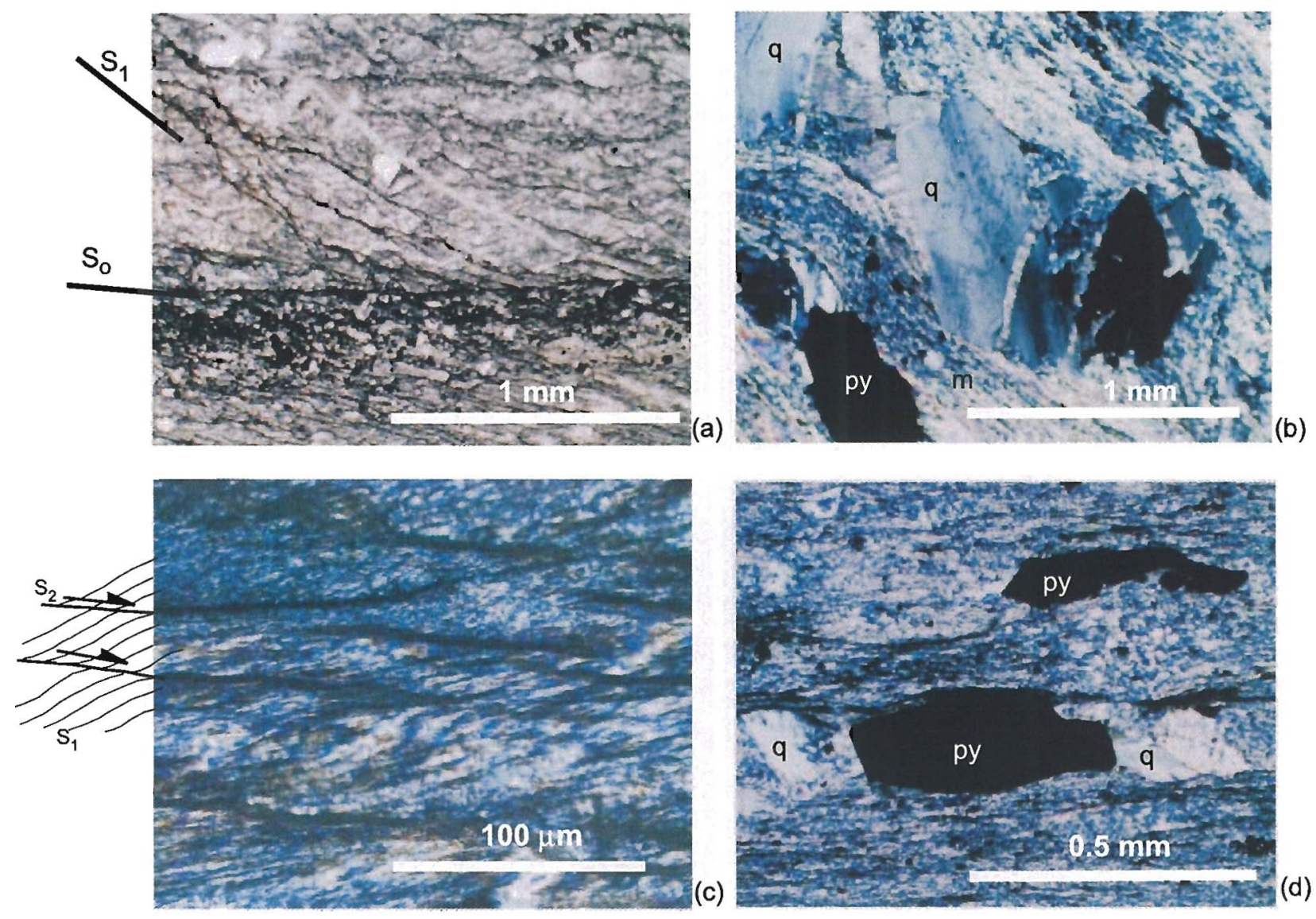

and Buttle upJifts (Fig. 11). At Myra Falls, D, fold structures are present throughout the Devonian sequence. For example, bedding in the Thelwood Formation, which sits stratigraphically above the ore-bearing Myra Formation, is also folded about a northwest-trending axis (Fig. 12). However, it is unclear whether D, folcting affects the Permian Buttle Lake Group, which unconformably overlies the Sicker Group. At Karst Creek, $14 \mathrm{~km}$ north of Myra Falls VHMS camp, bedding measurements in the Buttle Lake Limestone indicate a similar fold axis orientation to the underlying Sicker Group (Fig. 12). Muller (1980) reported areas, such as Museum Creek and south of Horne Lake, where the limestone is folded together with the underlying strata.

\section{$\mathrm{D}_{2}$ shear zones (Early to Middle Jurassic)}

Renewed northeast-southwest shortening during $\mathrm{D}_{2}$ produced a second steeply northeast-dipping fabric (S2)' The S2 foliation is developed in localized zones and overprints SI' with the development of an extensional crenulation cleavage (Fig 10c). A wall map ofunderground drive B390 in the HW mine (Fig. 13), illustrates the gradual change from the weakly developed $\mathrm{S}$, foliation on the right side of the map to a strongly foliated shear zone. Within the shear zone the S, foliation and $\mathrm{F}$, fold axes appear to be rotated by about $10^{\circ}$ $15^{\circ}$ clockwise. The strong fabric in the shear zone is a composite $\mathrm{S},-\mathrm{S} 2$ fabric and a slightly steeper minerallineation is developed on the $\mathrm{S},-\mathrm{S} 2$ surface. A secondary cleavage is locally developed in the shear zone and overprints the S,-S2 foliation as an extensional crenulation cleavage. However, none of the rocks show evidence far strong rotational strain, and we do not interpret these as evidence for mylonite formation. The S2 foliation is also observed in other shear zones throughout the HW and Battle mines where a second cleavage overprints the SI foJiation (Fig. 10). As no $F_{2}$ folds were found, and the $S$, to $S 2$ angle is low, we conclude that the major affect of $\mathrm{D}_{2}$ was to tighten $\mathrm{D}$, folds .

The formation of a second foliation in the Sicker Group rocks has been reported elsewhere in the Buttle Lake and Cowichan uplifts, with a second phase of folding defined by the refolding of lineations and crenulation of the axial planar 
Fig. 11. Correlation of regional deformation events from northem, cenlral, and southern Vancouver Island.

\begin{tabular}{|c|c|c|c|c|c|}
\hline & $\begin{array}{l}\text { Lale Devonian } \\
\text { to earliest Mississipian }\end{array}$ & $\begin{array}{l}\text { Middle Permian to pre-Middle } \\
\text { Triassic (post Bullie Lake Group } \\
\text { pre-Karmutsen Formation) }\end{array}$ & $\begin{array}{l}\text { Late Triassic } \\
\text { (syn-Karmutsen } \\
\text { Formation) }\end{array}$ & \multicolumn{2}{|c|}{$\begin{array}{l}\text { Early to Middle Jurassic } \\
\text { (Post Bonanza Group) }\end{array}$} \\
\hline Muller 1980 & & $\begin{array}{l}\text { NW-trending assymetrical folds } \\
\text { with axial planar cleavage variably } \\
\text { developed; horizontallineations; } \\
\text { refolding ofaxial planar cleavage } \\
\text { and lineations is rare; may } \\
\text { postdate Bullie Lake Group (?) }\end{array}$ & & & \\
\hline $\begin{array}{l}\text { England and } \\
\text { Calon 1991; } \\
\text { southem } \\
\text { Vancouver } \\
\text { Island } \\
\text { (Cowlchan } \\
\text { Uplift) }\end{array}$ & & & & \multicolumn{2}{|c|}{$\begin{array}{l}\text { Oevelopment of three major } \\
\text { NW-trending anticlinoriums, } \\
\text { cored by Paleozoic Sicker Group }\end{array}$} \\
\hline $\begin{array}{l}\text { Massey 1992; } \\
\text { southern } \\
\text { Vancouver } \\
\text { Island } \\
\text { (Cowichan } \\
\text { Uplift) }\end{array}$ & $\begin{array}{l}\text { Large scale open } \\
\text { folding - timing of } \\
\text { deformation } \\
\text { indicated by an } \\
\text { angular } \\
\text { unconformitity } \\
\text { between the Fourth } \\
\text { Lake Group and the } \\
\text { underlying Sicker } \\
\text { Group in Cowichan } \\
\text { Uplift }\end{array}$ & $\begin{array}{l}\text { Middle Permian to pre-Middle } \\
\text { Triassic W to NW-trending } \\
\text { SW-verging asymmetrical folds } \\
\text { with axial planar cleavage and } \\
\text { subhorizontallineations }\end{array}$ & $\begin{array}{l}\text { Extensive } \\
\text { crustal dilation } \\
\text { during the Late } \\
\text { Triassic } \\
\text { evolution } \\
\text { ofthe } \\
\text { Karmutsen } \\
\text { volcanic } \\
\text { sequence }\end{array}$ & \multicolumn{2}{|c|}{$\begin{array}{l}\text { Pre-Nanaimo Group deformation with } \\
\text { regional-scale warping of Vancouver } \\
\text { Island producing three major anticlinal } \\
\text { uplifts cored by Sicker Group rocks } \\
\text { Faulting, often axial, accompanied } \\
\text { this deformation event } \\
\text { A crenulation cleavage is oblique to SI } \\
\text { and appears to be axial to broad } \\
\text { open warps (possibly related to this } \\
\text { regional-scale warping of Vancouver } \\
\text { Island }\end{array}$} \\
\hline $\begin{array}{l}\text { Yorath et al. } \\
\text { 1999; south- } \\
\text { central } \\
\text { Vancouver } \\
\text { Istand }\end{array}$ & \multicolumn{2}{|c|}{$\begin{array}{l}\text { Paleozoic Sicker Group rocks have two fold phases present } \\
\text { (in comparison to the overlying Karmutsen Formation, which } \\
\text { has only one). A moderate to strong foliation is developed axial } \\
\text { planar to subsidiary folds within core zones of the major } \\
\text { anticlinal structures (eg. Cowichan and Bullie Lake uplifts). } \\
\text { The fold axes of these subsidiary folds are parallel and oblique } \\
\text { to the trend of the major anticlinal structures }\end{array}$} & & \multicolumn{2}{|c|}{$\begin{array}{l}\text { One fold phase, comprising broad } \\
\text { open folds is present in the Karmutsen } \\
\text { Formation with dips on folded limbs } \\
\text { ranging from } 15^{\circ} \text { to } 35^{\circ} \text {; The overlying } \\
\text { Bonanza Group is also folded }\end{array}$} \\
\hline $\begin{array}{l}\text { Nixon etal. } \\
1994 ; \\
\text { northern } \\
\text { Vancouver } \\
\text { Island }\end{array}$ & & & & \multicolumn{2}{|c|}{$\begin{array}{l}\text { Post Early Jurassic to } \\
\text { pre-Cretaceous compressional } \\
\text { event resulted in regional tilting } \\
\text { and formation of the Victoria } \\
\text { Arch, accompanied by f1exural } \\
\text { slip folding and faulting }\end{array}$} \\
\hline This study & $\begin{array}{l}\text { Pre-Permian NE-SW } \\
\text { compression resulted in } \\
\text { NW-oriented assymmetric } \\
01 \text { folds and developed } \\
\text { axial planar foliation with } \\
\text { subhorizontal lineations }\end{array}$ & & & $\begin{array}{l}\text { Post Early Jurassi } \\
\text { compressional eve } \\
\text { formation of the B } \\
\text { localized NW-orier } \\
\text { and tightening of }(\end{array}$ & $\begin{array}{l}\text { pre-Cretaceous } \\
\text { resulted in } \\
\text { Lake Uplift and } \\
02 \text { shear zones } \\
\text { olds }\end{array}$ \\
\hline $\begin{array}{l}\text { Tectonlc } \\
\text { Events }\end{array}$ & \multicolumn{3}{|c|}{$\begin{array}{l}\text { Early deformation of Wrangellia prior to collision with the } \\
\text { North American plate margin }\end{array}$} & $\begin{array}{l}\text { sion of Wrangellia } \\
\text { North America; } \\
\text { onal scale warping } \\
\text { formation of major } \\
\text { :linal structures }\end{array}$ & $\begin{array}{l}\text { Intrusion of Island } \\
\text { Intrusive Suite }\end{array}$ \\
\hline
\end{tabular}


Fig. 11 (concluded).

\begin{tabular}{|c|c|c|c|c|}
\hline \multicolumn{3}{|c|}{$\begin{array}{l}\text { Tertiary } \\
\text { Cretaceous }\end{array}$} & Eocene & post Eocene \\
\hline \multirow{2}{*}{\multicolumn{2}{|c|}{$\begin{array}{l}\text { A set of } \mathrm{N} \text { to NE-trending faults } \\
\text { may predate the Eocene } \\
\text { NW-trending faults }\end{array}$}} & $\begin{array}{l}\text { Deposition of } \\
\text { Nainamo Group }\end{array}$ & $\begin{array}{l}\text { Major NW-trending faults postdate } \\
\text { deposition of the Nanaimo Group } \\
\text { sediments, } \\
\text { eg., Cowichan Lake Fault }\end{array}$ & $\begin{array}{l}\text { post Eocene (?) NW-trending } \\
\text { faults }\end{array}$ \\
\hline & & $\begin{array}{l}\text { Extension and } \\
\text { formalion of Nanaimo } \\
\text { and Comox basins } \\
\text { with deposition of the } \\
\text { late Cretaceous } \\
\text { Nanaimo Group }\end{array}$ & $\begin{array}{l}\text { Large-scale W to NW trending } \\
\text { SW-verging thrust faults form } \\
\text { the Cowichan fold-thrust belt; } \\
\text { most thrust faults become } \\
\text { listric at depth }\end{array}$ & \\
\hline & & $\begin{array}{l}\text { Deposition of } \\
\text { Nainamo Group }\end{array}$ & $\begin{array}{l}\text { Large-scale } W \text { to } N W \text { trending } \\
\text { SW-verging thrust faults of probable } \\
\text { late Cretaceous to late Eocene } \\
\text { age. Most are high angle reverse } \\
\text { faults with dips between } 45^{\circ} \text { and } \\
90^{\circ} \text { and in places parallel the earlier } \\
\text { axial foliation in Paleozoic rocks. }\end{array}$ & $\begin{array}{l}\text { NNE trending vertical cross } \\
\text { faults, eg, Copper Canyon } \\
\text { Fault, offset NW-trending } \\
\text { thrust faults with apparent } \\
\text { sinistral sense; } \\
\text { possible Miocene age }\end{array}$ \\
\hline & & & $\begin{array}{l}\text { Major NW-trending faults } \\
\text { developed during Eocene } \\
\text { emplacement of the Pacific Rim } \\
\text { and (or) Crescent terranes beneath } \\
\text { Wrangellia }\end{array}$ & $\begin{array}{l}\mathrm{N} \text {-trending faults offset } \\
\text { the NW-trending faults } \\
\text { suggesting post-Eocene } \\
\text { movement; displacement } \\
\text { sense is unclear }\end{array}$ \\
\hline \multirow[t]{2}{*}{$\begin{array}{l}\text { Deposition } \\
\text { ofmid } \\
\text { Cretaceous } \\
\text { Coal } \\
\text { Harbour } \\
\text { Group }\end{array}$} & $\begin{array}{l}\text { Post mid Cretaceous and } \\
\text { pre-Late cretaceous } \\
\text { northerly directed } \\
\text { compression produced } \\
\text { NW-trending strike-slip } \\
\text { and lesser thrust } \\
\text { faults with oblique-dextral } \\
\text { movementon } \\
\text { NW-oriented faults and } \\
\text { sinistral movement } \\
\text { on NE-oriented faults }\end{array}$ & $\begin{array}{l}\text { Deposition of late } \\
\text { Cretaceous } \\
\text { Nanaimo Group }\end{array}$ & & $\begin{array}{l}\text { NE to ENE-trending normal } \\
\text { faults formed during Miocene } \\
\text { extension and formalion of } \\
\text { Queen Charlotte Basin; } \\
\text { post postdates deposition of } \\
\text { Upper Cretaceous Nanaimo } \\
\text { Group sediments; } \\
\text { Minor reactivation of } \\
\text { preexisling strike-slip } \\
\text { faults and Tertiary dikes } \\
\text { intrude faults during } \\
\text { this deformation event }\end{array}$ \\
\hline & $\begin{array}{l}\mathbf{0 3} \text { conjugate strike-slip } \\
\text { faults and minor thrusts } \\
\text { formed during north- } \\
\text { south compression }\end{array}$ & $\begin{array}{l}\mathbf{0 4} \text { normal faults } \\
\text { formed during } \\
\text { north-south extension } \\
\text { and basin formation } \\
\text { (predate large Eocene } \\
\text { thrust faults) }\end{array}$ & $\begin{array}{l}\mathbf{0 5} \text { W to NW-oriented sinistral } \\
\text { strike-slip faults and NE-dipping } \\
\text { thrust faults with top to the } \\
\text { Wand SW displacement }\end{array}$ & $\begin{array}{l}\text { Possible late (post-Eocene } \\
\text { steep NE-trending } \\
\text { sinistral faults }\end{array}$ \\
\hline & $\begin{array}{l}\text { North-south compression } \\
\text { (northern and central } \\
\text { Vancouver Island) }\end{array}$ & $\begin{array}{l}\text { Extension and formation } \\
\text { of the Nanaimo basin }\end{array}$ & $\begin{array}{l}\text { Accretion of Pacific Rim } \\
\text { and Crescent terranes } \\
\text { and formation of SW-verging } \\
\text { NW-trending Cowichan fold- } \\
\text { thrust belt }\end{array}$ & $\begin{array}{l}\text { Extension and opening } \\
\text { of Queen Charlotte basin } \\
\text { (northern Vancouver Island) }\end{array}$ \\
\hline
\end{tabular}


Fig. 12. Regional bedding measurements in Thelwood Formation and Buttle Lake limestone.

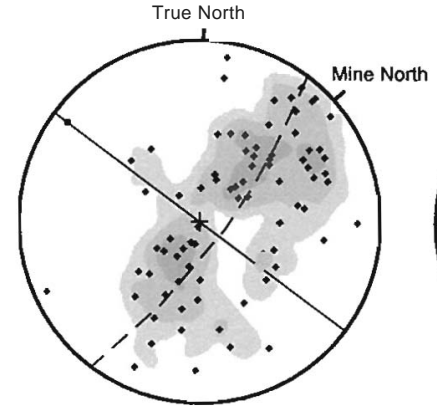

- Poles to bedding In Myra Formation

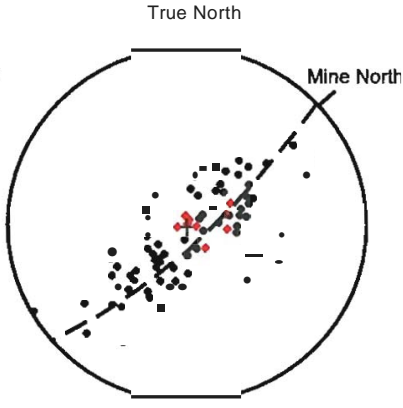

Poles to bedding in Thelwood Formation

- data from thls sludy

- data from Juras (1987)

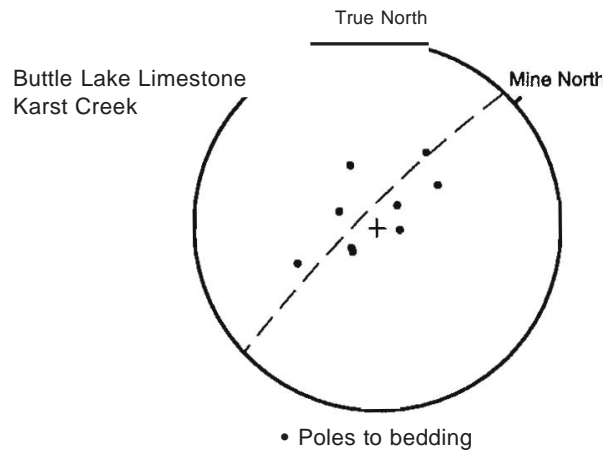

cleavage (Muller 1980; Massey 1992; Yorath et al. 1999). The secondary foliation and crenulations are only developed in the Sicker Group rocks, in the core zones of the large uplift zones. No cleavage is developed in the overlying Karmutsen Formation, probably reflecting the rheological contrast (England and Calon 1991; Yorath et al. 1999).

$\mathrm{D}_{3}$ faults (?post-Middle Cretaceous, pre-Late Cretaceous) Northeast-southwest compression during $\mathrm{D}_{3}$ produced two-stages of faulting with early steep, strike-slip faults $\left(\mathrm{D}_{3} \cdot\right.$ structures) overprinted by thrust faults and bedding-parallel shears $\left(D_{3 b}\right.$ structures). The interpreted $D_{3}$ fault pattern at Myra Falls is illustrated in Fig. 14. $\mathrm{D}_{3}$ faults are mostly minor structures and are too numerous to show at the property scale, with the exception of the Lynx-Phillips and MyraPrice Faults. However, the anisotropic pattern established by $\mathrm{D}_{3}$ faulting is important, as it influences later deformation, with many $D_{3}$ structures reactivated by the $D_{4}$ and $D_{S}$ events.

\section{$D_{3 a}$ strike-slip faults}

$\mathrm{D}_{3 \mathrm{a}}$ faults are typically planar structures with well-developed coarse quartz-chlorite-epidote slickenfibres and chloritic polished surfaces. The fault striations are shallowly plunging and no fault gouge was found associated with these faults. The faults are predominantly steeply dipping to vertical and have a wide range of strikes. There is a consistent fault displacement pattern, with sinistral faults striking east to southeast and dextral faults striking north to north-northeast (Fig. 14). $\mathrm{D}_{3 \mathrm{~s}}$ faults are common, and offsets are typically
$<1 \mathrm{~m}$. The large Myra-Price Fault and the Lynx-Phillips Fault have similar orientations to the $\mathrm{D}_{3^{\bullet}}$ minor faults. Individual synthetic minor faults that occur near the Myra-Price and Lynx-Phillips Faults were active during $\mathrm{D}_{3 . \text {., and the }}$ offsets on the regional scale faults is consistent with movements predicted during $D_{3 a}$. The Myra-Price and LynxPhillips Faults faults postdate $D_{2}$. Thus, we conclude these faults were formed during $\mathrm{D}_{3 \mathrm{a}}$. Subsequent reactivation during the $D_{S}$ event has have destroyed early $D_{3}$. fabrics on some fault surfaces and the Myra-Price fault has been strongly reactivate during $\mathrm{D}_{\mathrm{S}}$ (see later in the text). Figure $15 b$ illustrates the effects of $\mathrm{D}_{3}$. faulting on the position of ore blocks in the Battle Mine. Large north-dipping sinistral $D_{S}$ faults crosscut the $D_{3}$. faults. The consistent $D_{3}$. fault pattern of north-striking dextral faults and east-striking sinistral faults, suggests that these faults formed during a single northeast-southwest shortening event.

\section{$D_{3 b}$ thrust faults}

$\mathrm{D}_{3 \mathrm{~b}}$ faults differ markedly from the $\mathrm{D}_{3}$. faults in their geometry, kinematics, and morphology. The $\mathrm{D}_{3 \mathrm{~b}}$ faults generally strike northwest and have moderate to shallow northeast and southwest dips (Fig. 14). They are common throughout the area, but are less visible than the steep $\mathrm{D}_{3}$. faults, as they commonly develop as bedding-parallel shears. They are wavy, slightly anastomosing struclures with minor gouge. Slickenfibres are common, usually comprising quartz-chlorite and minor epidote fibres. Zones of cleaved rock, up to $10 \mathrm{~cm}$ wide, are developed in the wall rocks. $D_{3 b}$ faults consistently offset $\mathrm{D}_{3}$. faults, and the displacement sense on most northeastdipping $\mathrm{D}_{3 \mathrm{~b}}$ faults is top to the west and on southwestdipping $D_{3 b}$ faults, top to the east. Where measured, offsets on the $D_{3 b}$ faults are $<2 \mathrm{~m}$.

$D_{3 b}$ faults are Jess common and Iess consistent than the $\mathrm{D}_{3} \cdot$ fault set, possibly because of difficulties in separating some $\mathrm{D}_{3 \mathrm{~b}}$ faults from $\mathrm{D}_{\mathrm{S}}$ faults. However, the geometry and kinematics of the $D_{3 b}$ faults are consistent with a single stress orientation, and fault striation analysis indicates a subhorizontal east-trending $\sigma_{1}$. The change in fault style from $D_{3} \cdot$ and $D_{3 b}$ is caused by a switch in the orientation of $\sigma_{2}$ and $\sigma_{3}$. Figure 16 illustrates the change in stress states from $\mathrm{D}_{3}$. to $\mathrm{D}_{3 \mathrm{~b}}$ deformation with a two stage evolution of strikeslip faults, followed by shallow thrust faults.

Nixon et al. (1994, 1995) mapped a similar series of strikeslip faults and lesser thrust faults in northern Vancouver Island (Fig. 11). These faults postdate deposition ofthe midCretaceous Coal Harbour Group and may predate the Late Cretaceous Nanaimo Group. The faults form the dominant northwest-striking structures in the area and are thought to be the result of north-directed compression. These northweststriking faults display oblique dextral motion with antithetic northeast-striking faults displaying sinistral, northwest-side-up displacement. Minor northwest-striking thrust faults, with a south-side-up motion have also been observed. Substantial strain has also been accommodated by flexural slip folding and bedding-parallel shear (Nixon et al. 1994, 1995).

\section{$\mathrm{D}_{4}$ normal faults (?Late Cretaceous)}

Extension during $\mathrm{D}_{4}$ produced steep normal faults with a wide array of orientations across the property (Fig. 17). $D_{4}$ faults predominantly strike east, north, and east-southeast 
Fig. 13. A second foliation develops in strong shear zones in drive B390, HW mine. This secondary fabric is observed in localized zones throughout the HW and Battle mines.

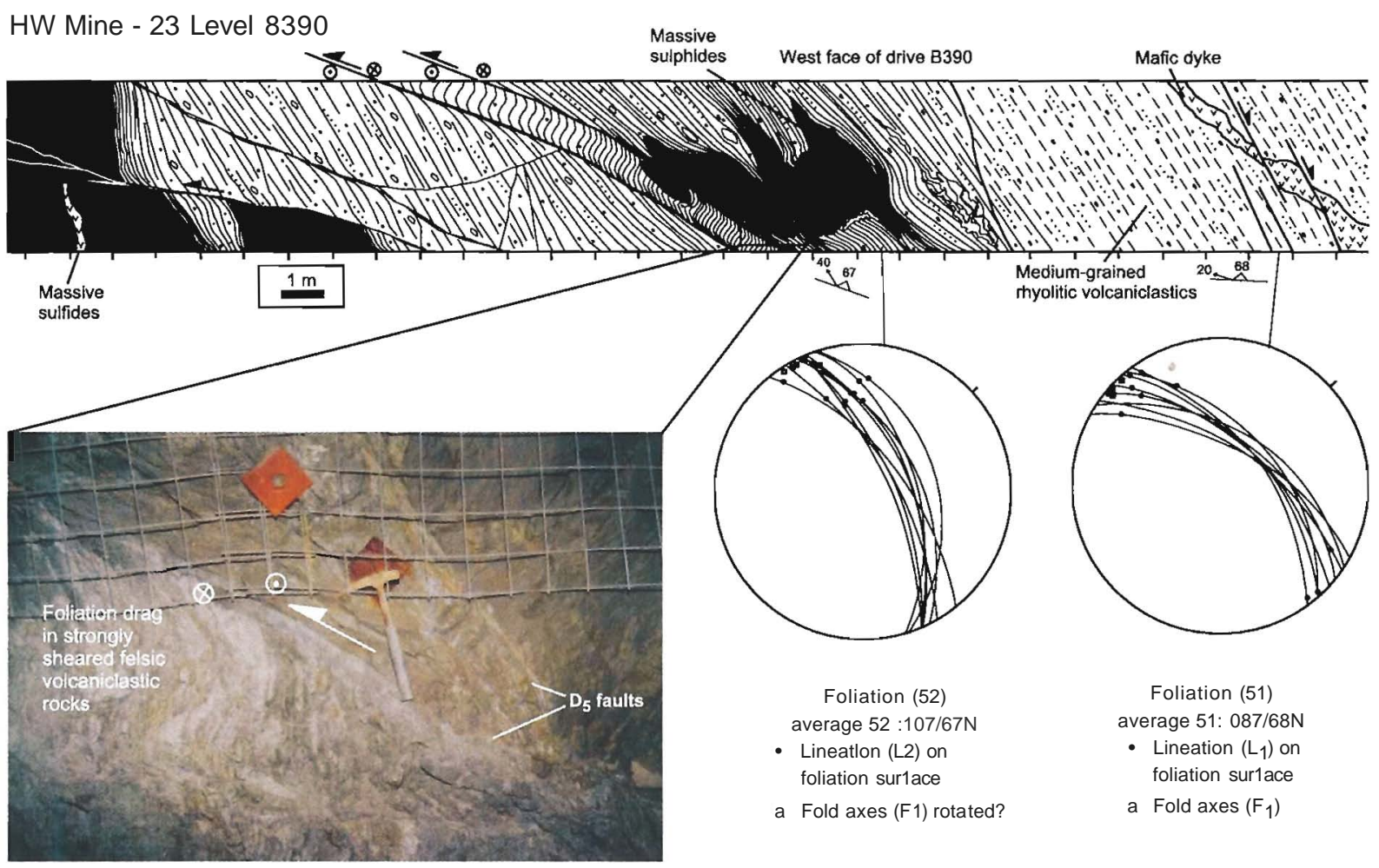

Fig. 14. Interpreted fault pattern for the $\mathrm{D}_{3 \mathrm{a}}$ and $\mathrm{D}_{3 \mathrm{~b}}$ faults at Myra Falls with measured faults shown in stereoplots.

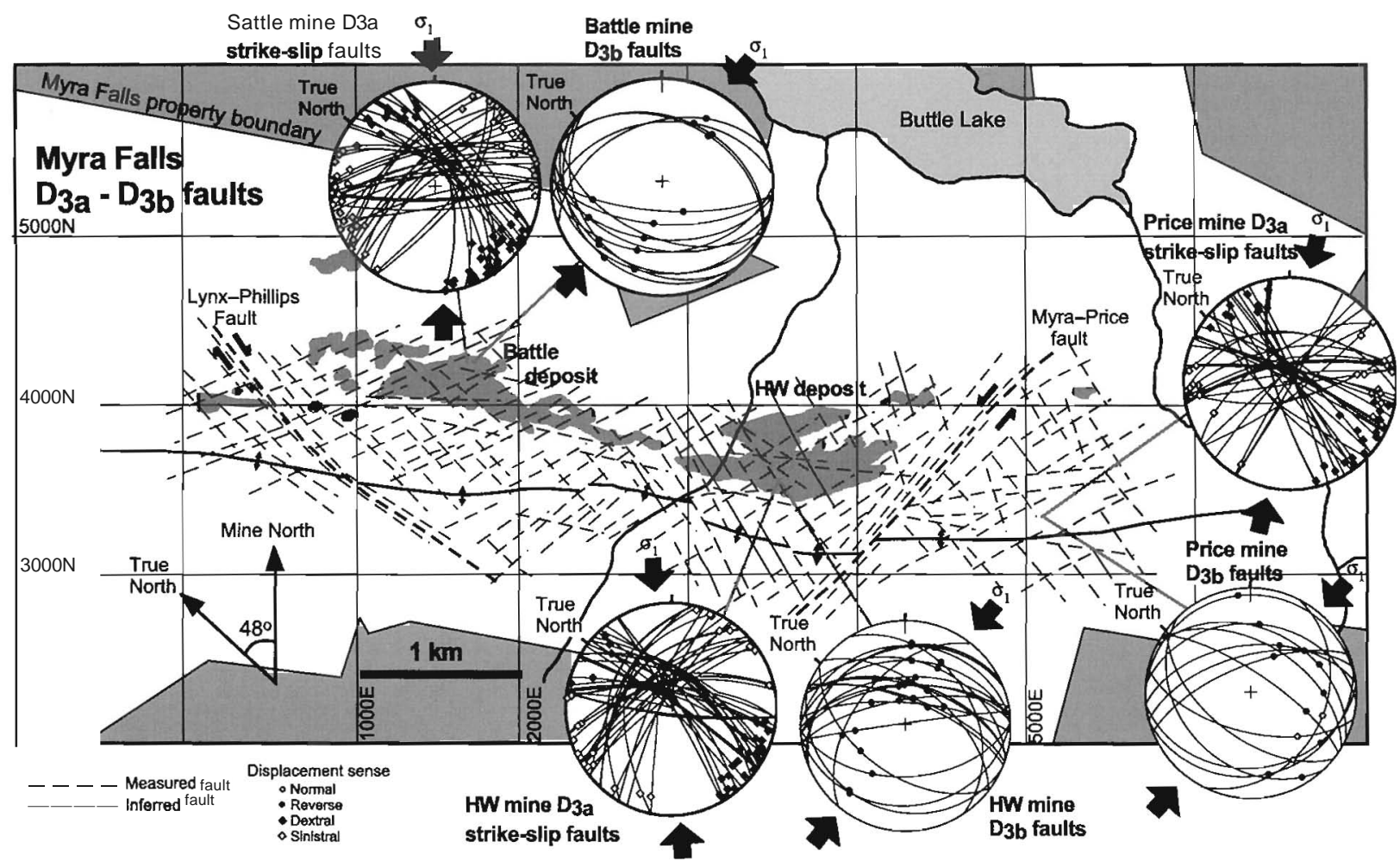


Fig. 15. (a) Footwall contour map of the Gopher Zone, Sattle Mine; (h) mapping indicates the strong fault contro! on the position of ore blocks in the Gopher lens, Battle Mine. $\mathrm{O}_{2}$ and 05 struetures appear to be the dominant faults, but the conjugate 0 3a faults also have a significant effect.
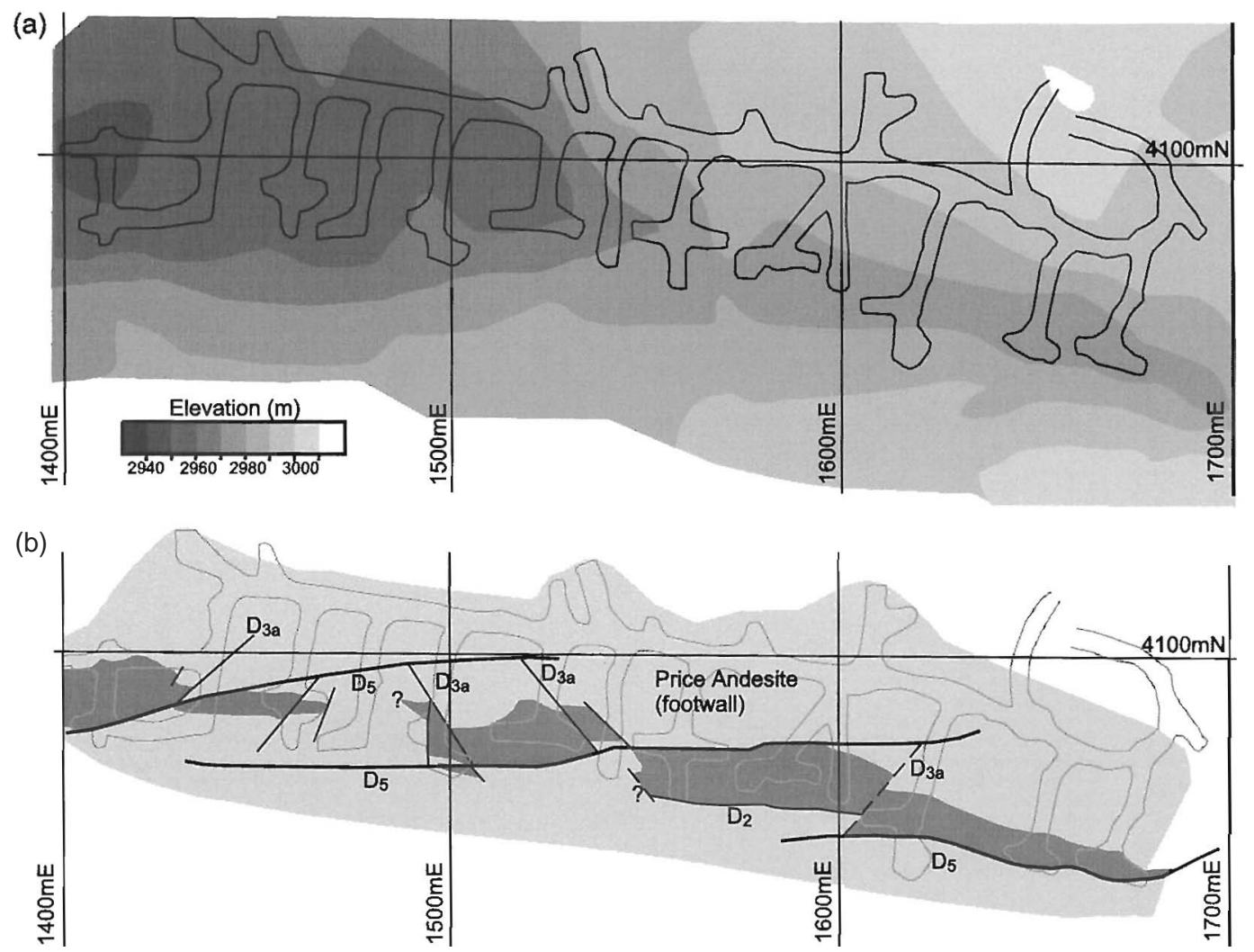

Fig. 16. Block diagrams illustrating (a) northeast-striking sinistral and northwest-striking dextra! 03a strike-s!ip faults, overprinted by (h) east-west-striking 0Jb thrust faults (diagrams modified from Homberg et al. 1999).
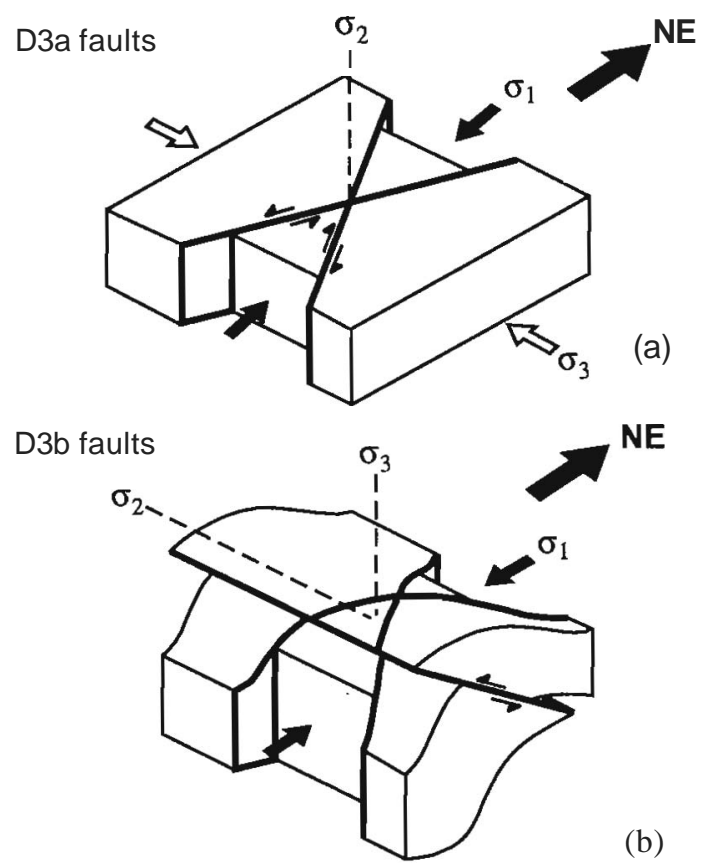

and are steeply dipping to vertical. They are planar, with minor gouge and fine steep quartz fibres, and are spatially associated with quartz-carbonate veining (Fig. 18). The $\mathrm{D}_{4}$ event reactivates steeply dipping $\mathrm{D}_{3 \mathrm{a}}$ faults. Shallow plunging $\mathrm{D}_{3 \mathrm{a}}$ striations are commonly grooved and (or) overgrown by steeply plunging $\mathrm{D}_{4}$ quartz fibres. Underground mapping and fault striation data indicate that the $\mathrm{D}_{4}$ normal faults postdate $D_{3}$ faults and are consistently offset by $D_{S}$ faults.

$\mathrm{D}_{4}$ normal faults are common across the property but are more abundant in localized zones, such as the East-Main Fault zone on the northwestem edge of the HW orebody and the North Fault zone, situated to the northeast of the Battle and HW orebodies. $\mathrm{D}_{4}$ quartz fibres crosscut and (or) overgrow $\mathrm{D}_{3 \mathrm{a}}$ fibres on fault surfaces within the East-Main Fault. The steep East-Main Fault is then crosscut and displaced by steep northeast-striking sinistral strike-sJip faults. No direct measurements were made of the North Fault zone, and this structure is interpreted as a $D_{4}$ fault based on the spatial clustering of small observable $\mathrm{D}_{4}$ faults nearby and the sinistral offset of the North Fault by the Myra-Price Fault (Fig. 5).

Although the overall displacement across larger fault zones is substantial (e.g., $>100 \mathrm{~m}$ on the North Fault zone and $\sim 50 \mathrm{~m}$ on the East-Main Fault zone) the offset on individual $\mathrm{D}_{4}$ faults is commonly $<10 \mathrm{~m}$, and faults are spaced 5-10 m apart. An example is shown in Fig. 18b, where massive sulfides of the main HW lens are downthrown $10 \mathrm{~m}$ and are now in fault contact with the footwall Price Andesite. 
Fig. 17. Interpreted fault pattern for the $\mathrm{D}_{4}$ faults at Myra Falls with measured faults shown in stereoplots.

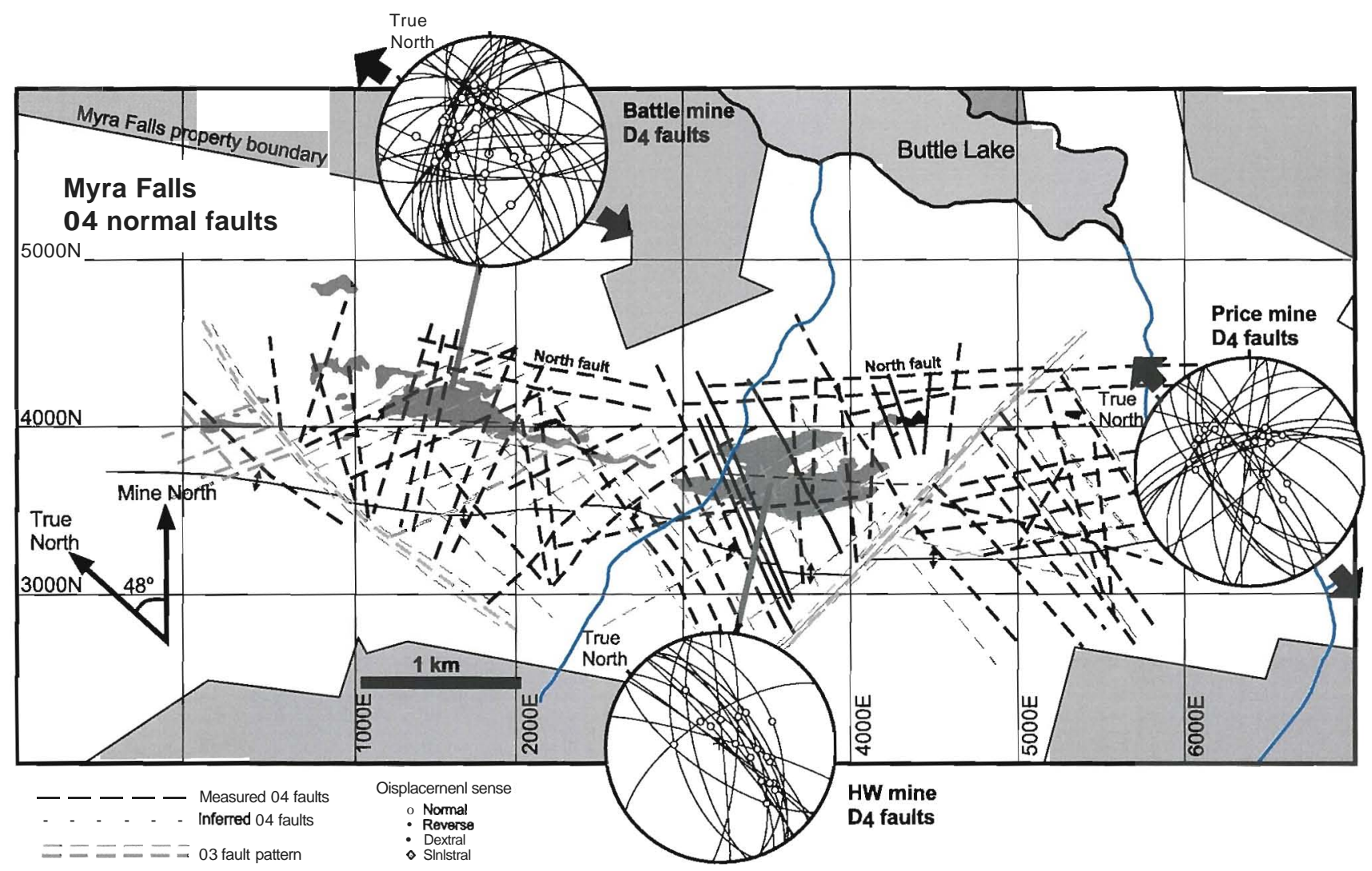

Bedding offsets are also visible in felsie volcaniclastic rocks in the 43 Block area of the HW mine and in road cuts, where normaloffsets are seen in finely laminated mudstone of the Thelwood Formation (Fig. 18a). Normal displacements are indicated by quartz-ehlorite sliekenfibres and by fauIt drag of bedding and foliation adjacent to the steep structures (Fig. 18c). The dominanee of east- and southeaststriking normal $\mathrm{D}_{4}$ faults in the Battle and Price Mines indicate a generally north-northeast extension. In the HW mine, north- and northeast-striking normal faults are dominant (Fig. 17). The lack of east- and southeast-striking normal faults in this area could represent a sampling problem or the reactivation of less favourably oriented north-striking $D_{3 a}$ faults. However, paleostress analysis of the $\mathrm{D}_{4}$ fault striations across all three mines using the method of Eteheeopar et al. (1981), suggest that the faults from all sites formed during NNE-SSW extension

\section{$\mathrm{D}_{\mathrm{S}}$ gouge-rieb oblique thrust faults and strike-slip} faults (Eoeene)

The $\mathrm{D}_{\mathrm{S}}$ event produeed large northwest-striking oblique thrust faults and steep strike-slip faults with northwest and northeast strikes. Large $D_{S}$ faults at Myra Falls include the reactivated Myra-Priee Fault zone and the Flat Fault (Fig. 19). $D_{S}$ structures differ markedly from earlier faults as they are gouge-rieh, wavy, anastomosing struetures and are eommonly assoeiated with irregular, clear to milky quartz veins and broad cleavage zones up to several metres wide (Fig. 20). $D_{S}$ sinistral strike-slip faults mostly dip steeply to the northeast and strike west to northwest. $D_{S}$ thrust faults predominantly have shallow to moderate northeast and southwest dips, with a consistent displaeement sense of top to the northwest on northeast-dipping faults and top to the east on southwest-dipping faults. Fault striations on strikeslip faults are shallow plunging to horizontal and are oblique on the shallow to moderately dipping thrust faults. Sliekenfibres are rare on these faults. Instead, fault striations are mostly fine grooves in the fault gouge and on fault surfaces. The sense of displacement on these faults is estimated from follation and bedding drag.

In many places, $D_{\mathrm{S}}$ structures appear to have large displacements, and this is evident in the footwall contours (Fig. 5). For example, a map of drive C355DD in the HW mine (Fig. 21) shows that the position of ore and rhyolitie hangingwall roeks is controlled by shallow-dipping oblique $\mathrm{D}_{\mathrm{s}}$ thrust faults, and $\mathrm{D}_{\mathrm{S}}$ faults offset many $\mathrm{D}_{3}$ and $\mathrm{D}_{4}$ faults. Foliation drag is commonly developed adjacent to the shallow to moderately dipping oblique $\mathrm{D}_{\mathrm{S}}$ thrusts (Fig. 13).

The $D_{S}$ faults occur as groups of faults spaced 1-5 m apart and form wide dismpted zones. A good example is shown by the cross-section through the Extension Zone, where the Flat Fault (an oblique $\mathrm{D}_{\mathrm{S}}$ thrust zone) offsets the ore horizon and is the dominant structure in this area (Fig. 22). Although offsets on individual fault strands are typically 1$10 \mathrm{~m}$, the overall displacement across the $10 \mathrm{~m}$ thick Flat Fault zone is more than $100 \mathrm{~m}$. The largest $\mathrm{D}_{\mathrm{S}}$ fault zone is the east-striking Myra-Priee Fault, which has a $300 \mathrm{~m}$ displacement, making it visible on the footwall contour map 
Fig. 18. Examples of nonnal faults at Myra Falls: (a) $\mathrm{D}_{4}$ nonnal faults offset laminated mudstone of the Thelwood Fonnation (roadcut $10 \mathrm{~m}$ high); (b) Massive sulfides are downthrown about $10 \mathrm{~m}$ along the East-Main fault and are now in fault contact with the footwall, Price Andesite, drive 23-331 XN, HW mine; (c) fault drag of bedding adjacent to a $\mathrm{D}_{4}$ fault indicates nonnal displacement.
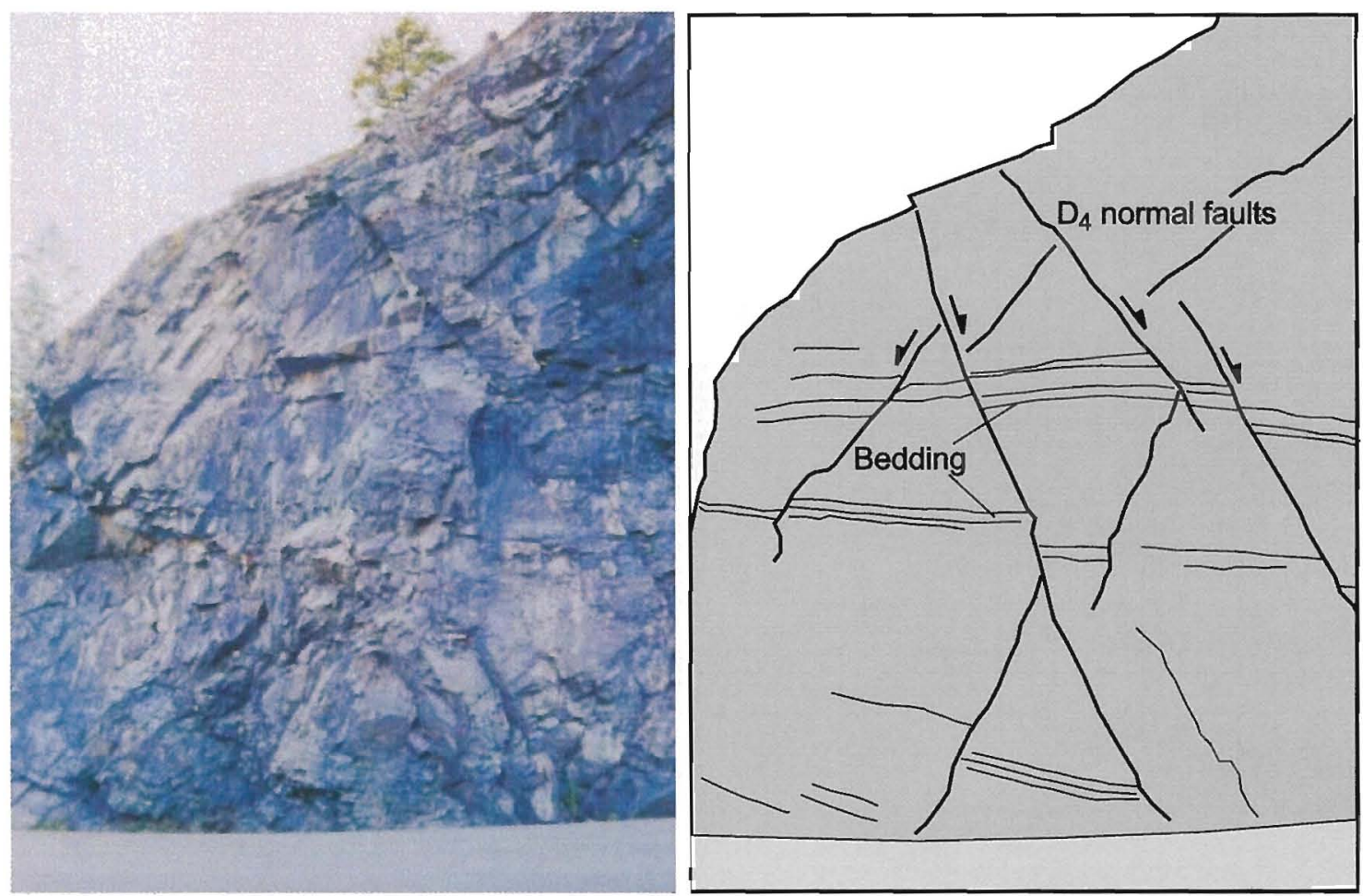

(a)
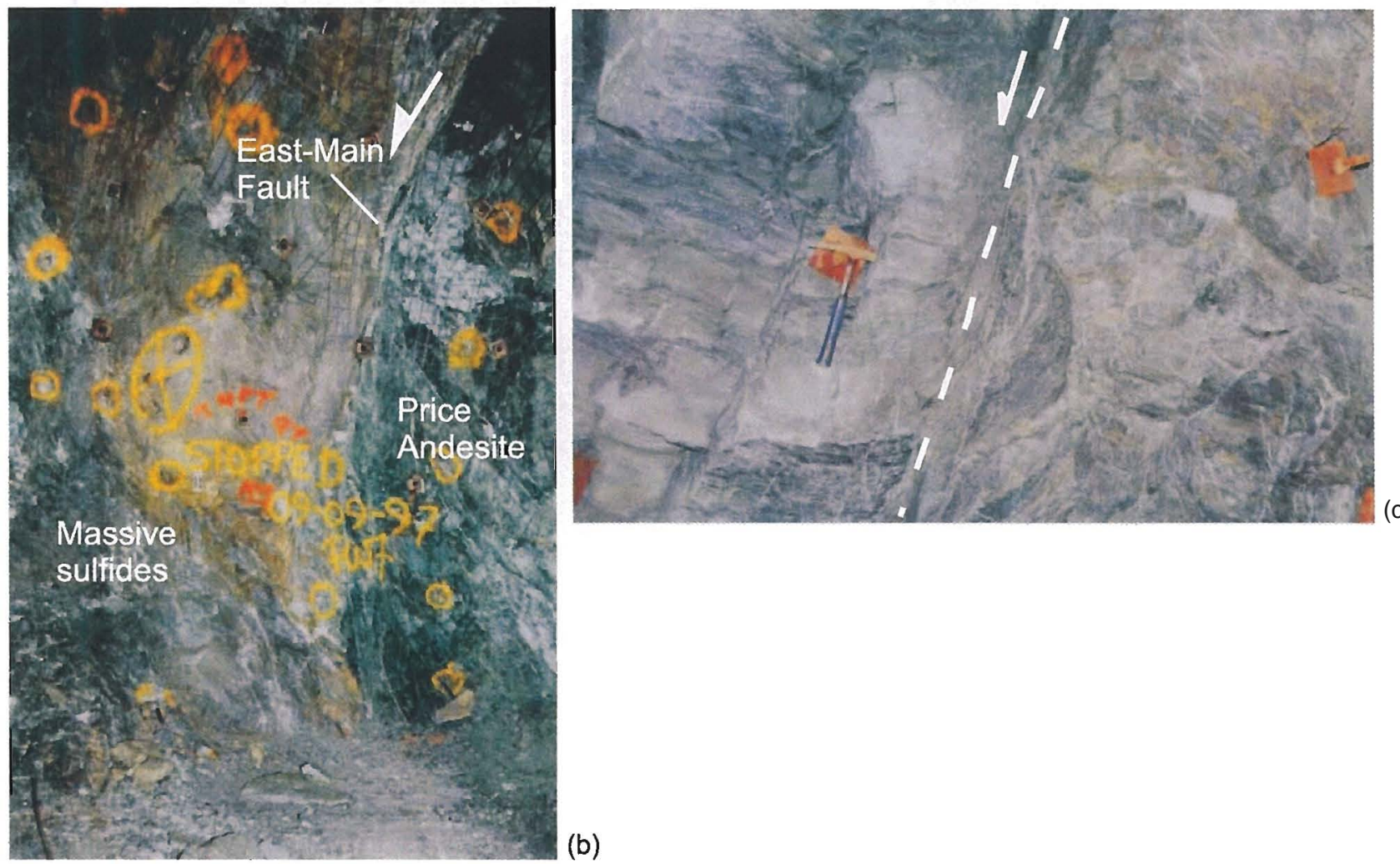

(b) 
Fig. 19. Interpreted $0_{5}$ fault pattern at Myra Falls with measured faults shown in stereoplots.

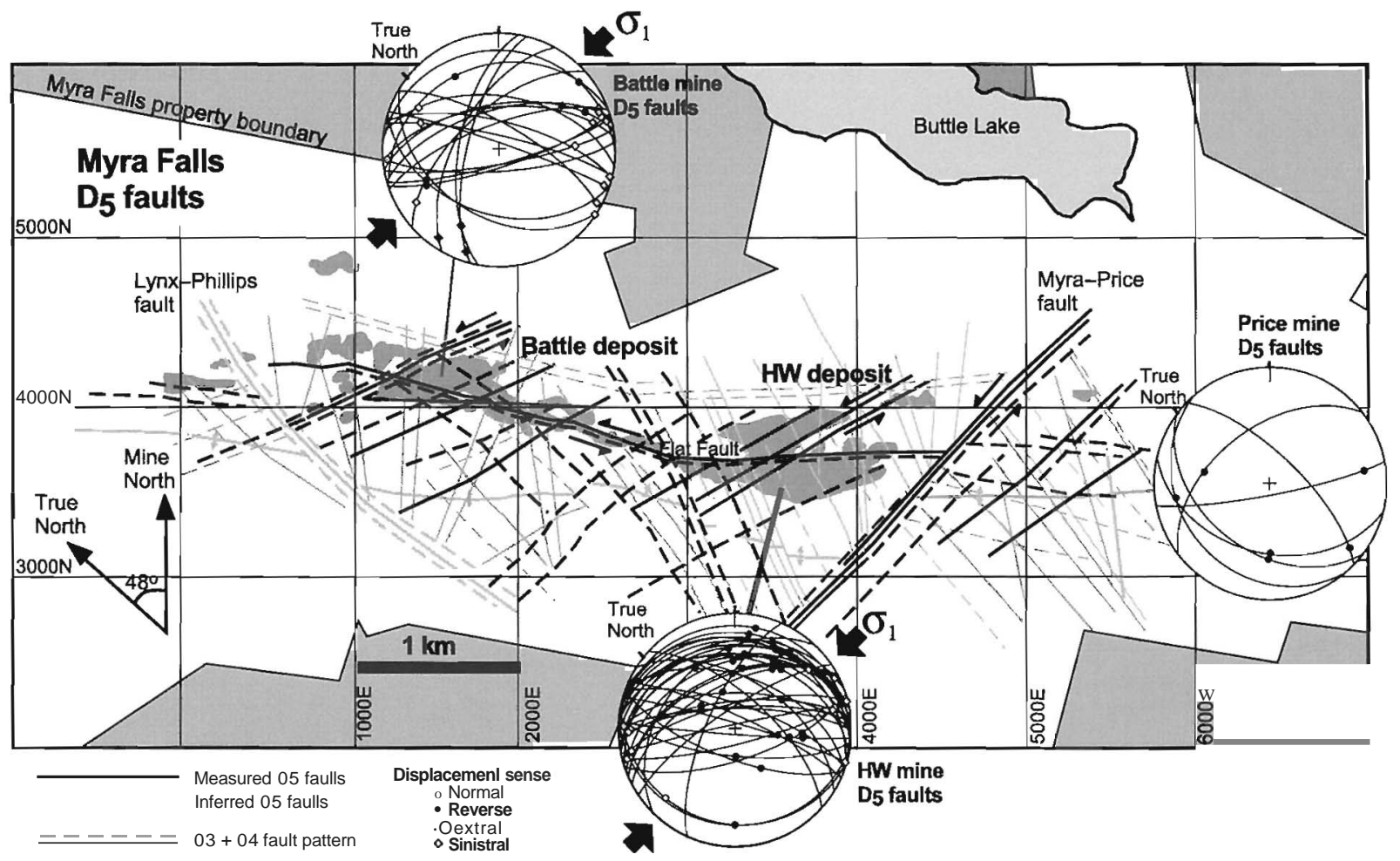

Fig. 20. Typical gouge-rich $0_{5}$ faults in the Battle and HW mines. (a) Sinistral strike-slip $0_{5}$ fault offsets a rhyolitic volcaniclastic unit in drive 23-427, HW mine; (b) a large gouge-rich $0_{5}$ fault with strong foliation drag adjacent to the structure indicating a top to the west sense of displacement (oblique thrust) in drive B390, HW mine; (e) fault gouge and quartz veining in a $0_{5}$ fault; veining indicates a sinistra] sense of displacement, drive ST] 83A, Battle mine.
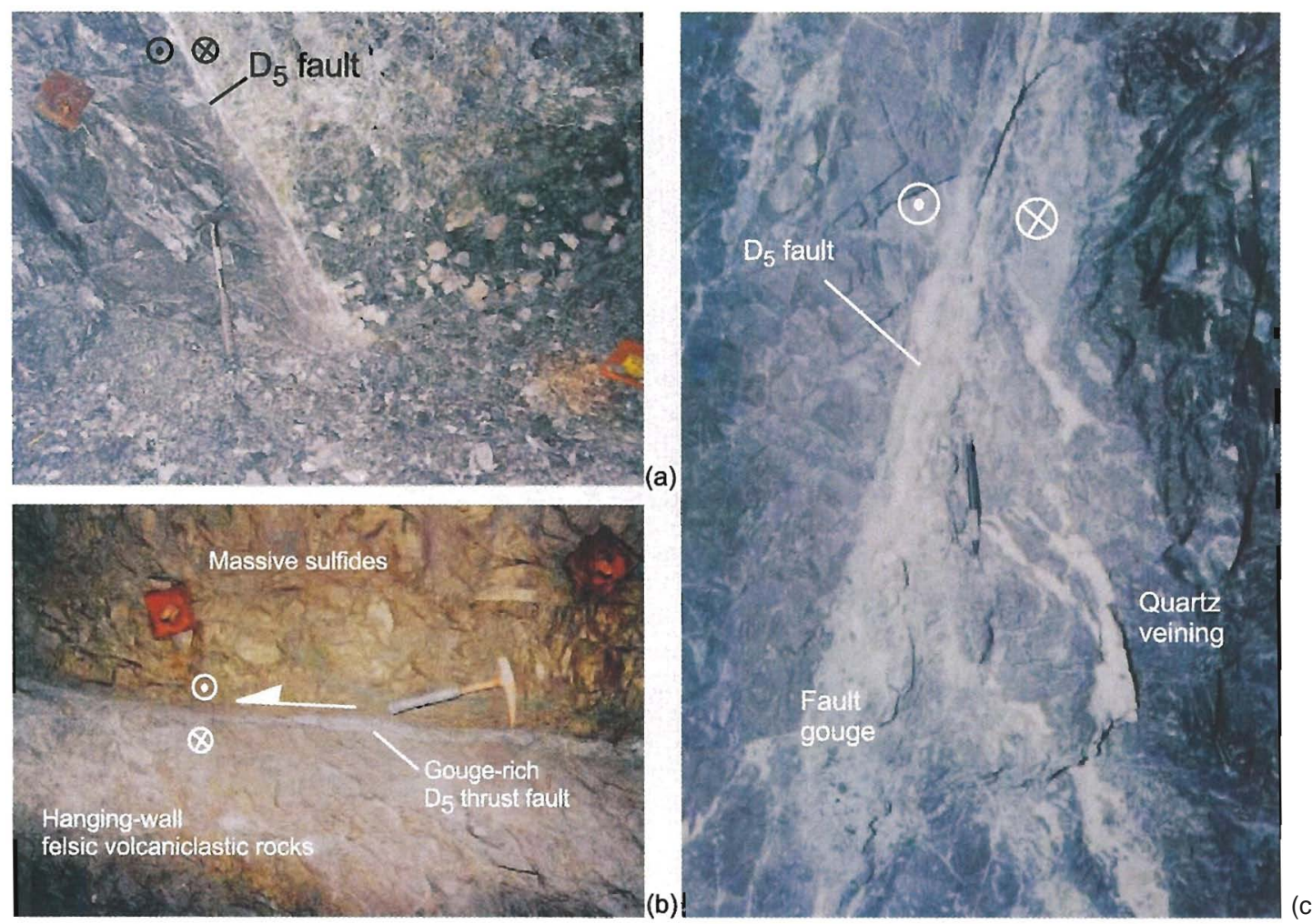
Fig. 21. Wall map of underground drive C35500, HW mine, the 05 faults here are the dominant structures, controlling the position of the massive sulfides.

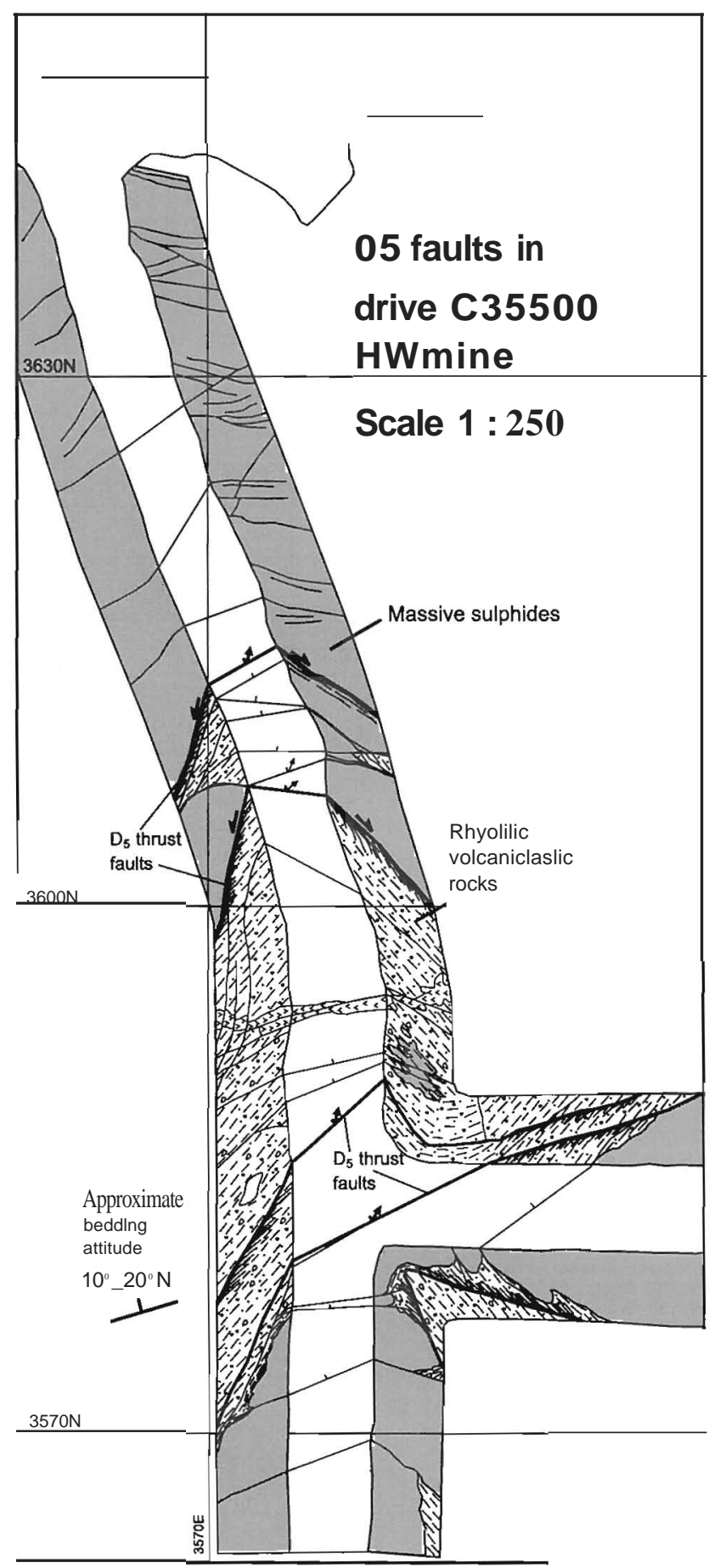

(Fig. 5). However, the calculated displacement on this fault probably includes a contribution from an earlier $\mathrm{D}_{\jmath}$ offset.

The steep strike-slip faults are coeval with the shallow thrusts, as these structures display mutually crosscutting relations. $\mathrm{D}_{\mathrm{S}}$ faults have a much greater degree of scatter than other fault groups discussed here. However, the distinct mor- phology of $\mathrm{D}_{\mathrm{S}}$ faults and their consistent timing relations suggest that they are related to a single tectonic phase, even though the striation data cannot be explained by a single stress orientation. The largest faults at Myra Falls (MyraPrice and Lynx-Phillips faults) were active during the $D_{S}$ event. The $D_{S}$ structures most likely formed during a single northeast-southwest compression event, in which large displacements resulted in local variations in the stress field. The reactivation of older $D_{J}$ structures during the $D_{S}$ event would also contribute to the significant scatter in the orientation of $\mathrm{D}_{\mathrm{S}}$ structures.

Numerous large west- to west-northwest-striking faults with apparent sinistral offset have been mapped in Strathcona Provincial Park by the Geological Survey of Canada, and several extend through Myra Falls VHMS camp (Fig. 3). These are correlated with the large west- to northwest-striking $\mathrm{D}_{\mathrm{S}}$ faults at Myra Falls. These faults have a similar orientation to major northeast-dipping thrust faults further south, such as the Beaufort Range and Cowichan Lake fault zones described by England and Calon (1991), Massey (1992), and Yorath et al. (1999) (Fig. 11). The faults postdate the Late Cretaceous Nanaimo Group and generally have dips ranging from $45^{\circ}$ to $90^{\circ}$. In places, they parallel the early axial foliation in the Paleozoic rocks (Massey 1992). Wide schistose zones develop around these faults in receptive lithologies, and faults have up to $2 \mathrm{~km}$ offset. Regional mapping by Massey (1992) suggests that fault movements are directed to the west and southwest, equivalent to sinistral movement on steep west-striking faults and oblique movement on the northwest-striking thrust faults. The orientation, morphology, and kinematics of these large Eocene structures are identical to the gouge-rich $\mathrm{D}_{\mathrm{S}}$ faults described at Myra Falls.

\section{Summary and discussion}

The early folding history of Vancouver Island is poorly known and is only recorded from the anticlinal zones or uplifts in central and southem areas, where two folding events of Paleozoic and Jurassie age have been observed (Fig. 11) (e.g., Yorath et al. 1999). Massey (1992) suggested that there was an earlier phase of late Devonian to earliest Mississipian open folding based on the presence of an angular unconformity at the base of the Fourth Lake Formation (Buttle Lake Group), on the southwest limb of the Cowichan Uplift (Massey 1992). The lack of a strong penetrative fabric in the Permian Buttle Lake Group also suggests that the tight folding associated with the development of a penetrative fabric in the Sicker Group was pre-Permian. However, the variation in fabric development may reflect rheological contrasts, with the Permian limestone acting more competently during deformation than the underlying Sicker Group volcanic rocks (Massey 1992).

Massey (1992) and Yorath et al. (1999) suggested a pre-Triassie age for the early folding and fabric development based on the fact that two phases of folding are observed in the Sicker Group rocks, while only one open fold phase is present in the overlying Karmutsen Formation. The early folding event is most likely the result of northeastsouthwest-directed compression within the WrangeJlia Terrane, prior to collision of WrangeJlia and the ancient margin of North America. Based on the weight of circumstantial evi- 
Fig. 22. Extension Zone seetion $2350 \mathrm{E}$ illustrating the large $\mathrm{D}_{\mathrm{S}}$ thrust (Flat Fault) that is the dominant structure in this area.

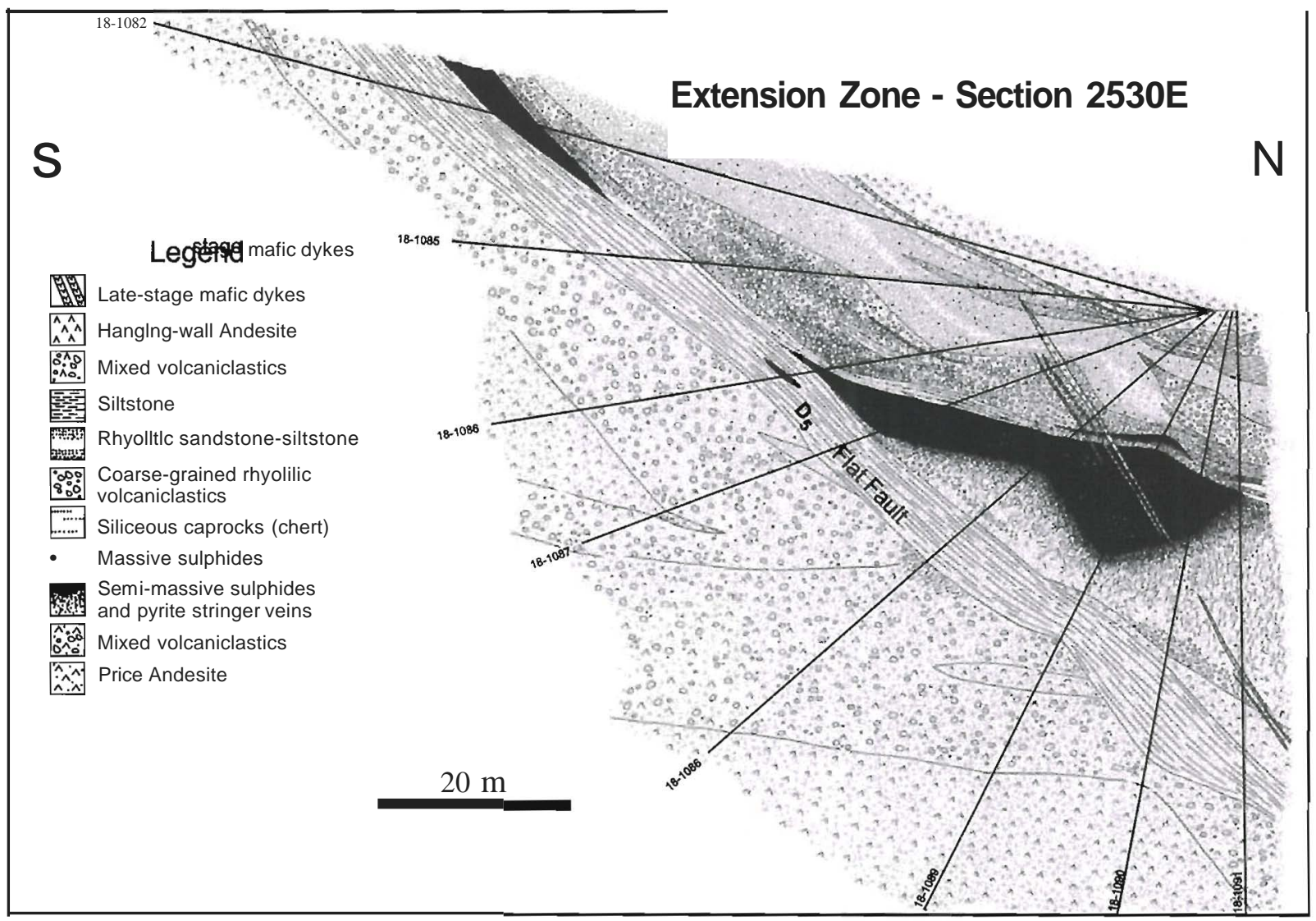

dence, we follow Massey (1992) and place the $\mathrm{D}_{1}$ folding older than the Middle Pennian Buttle Lake Group.

At Myra Falls, a second folding event tightens the D, open northwest-trending anticline_A second cleavage strikes $20^{\circ}$ clockwise of the early folds, but no new regional folds are produced. Instead, the original Myra Falls anticline is amplified and S2 foliation transects the regional folds. The oblique strain leads to localized shear zones in which SI foliation is dragged into parallelism with S2' This style of "Type 0" interference has been weil documented and leads to ambiguous field relationships (e.g., Ramsay and Huber 1987). Structural studies on Vancouver 1sland suggest that all the major northwest-trending anticlinal structures or "uplifts" in southern and central Vancouver 1sland are the result of amplification of pre-Pennian open folds .

The $\mathrm{D}_{2}$ folding event most likely produced the large regional-scale warping of Vancouver Island, during Early to Mid-Jurassic time (pre-Nanaimo Group). Three major northwest-trending anticlinal uplifts were formed, including the Cowichan and Buttle Lake uplifts (Fig. 11). Fabrics associated with this second phase of folding are best developed in the less competent rocks in the cores of the uplifts, indicating strong strain localization consistent with reactivation of F1 folds (Massey 1992; Muller 1980).

The Bonanza Group and older rocks are gently folded into broad anticlines with limb dips of $15^{\circ}-35^{\circ}$ in the Cowichan Uplift (Yorath et al. 1999) and axial faulting accompanied the folding (Massey 1992; Nixon et al. 1994). Regional-scale gentle f01ding, as a result of east- to northeast-directed compression, is also observed in northern Vancouver Island, where Bonanza Group sediments are folded to form the Victoria Arch (Nixon et al. 1994, 1995). A minimum age for this defonnation is indicated by the angular unconfonnity between the Jurassic sediments and the overlying Upper Cretaceous sediments of the Nanaimo Group. The folding may correlate with the collision and accretion of the Wrangellia Terrane with the Intermontane Belt, during mid to Late Jurassic and possibly as late as mid Cretaceous (Monger et al. 1982; Monger et al. 1985; Gabrielse and Yorath 1991; Massey 1992; Johnston 2001). Muller (1980) and Massey (1992) also suggest that the regional-scale warping of Vancouver Island was coeval with intrusion of the Jurassic Island Intrusives. The plutons display only minor deformation, suggesting syn- to post-kinematic emplacement of the igneous bodies.

The Cretaceous fault history at Myra Falls correlates weil with the events recorded by Nixon et al. (1994) in the north. The record is better at Myra Falls with an early strike slip event followed by thrusting. Aperiod of strong northeastsouthwest shortening is indicated by the development of $\mathrm{D}_{3 a}$ strike-slip faults, which form a conjugate set of steep northnortheast-striking dextral and west-northwest-striking sinistral faults and minor $D_{3 b}$ thrust faults. Myra Falls is the southern most exposure where this Cretaceous fault event has been described. The evidence from Myra Falls suggests that the Cretaceous $\mathrm{D}_{3}$ event can be distinguished from overprinting 
Eocene thrusts by the mineralogy and texture on the fault planes. The lack of any significant cleavage zone development around $\mathrm{D}_{3}$ faults at Myra Falls, and the presence of epidotechlorite slickenfibres suggest that these structures represent early ductile-brittle faults, associated with relatively hot fluids, as epidote is thought to grow at or above $240-260{ }^{\circ} \mathrm{C}$ (Browne 1978). The northeast-southwest to NNE-SSW compression direction estirnated for the $\mathrm{D}_{3}$ faults is similar to that estimated for the $\mathrm{D})$ and $D_{z}$ events. However, $\mathrm{D}_{3 \mathrm{a}}$ faults with epidote fibres, crosscut igneous rocks of the Island Intrusive Suite. This indicates that they are not a final brittle phase of the $D_{z}$ ductile deformation event. Instead, $\mathrm{D}_{3}$ faulting represents a later northeast-southwest cornpression event.

At Myra Falls, the $\mathrm{D}_{4}$ event is characterized by east, north, and east-southeast-striking normal faults and is consistent with development during north-south extension. Although the $\mathrm{D}_{4}$ faults are common in the Myra Falls area, they are not described on most regional maps. However, a significant period of extension is indicated by the development of the Late Cretaceous Nanaimo Basin, which is a subbasin of the extensive Georgia Basin (Fig. 1I). The Nanaimo Basin is thought to have developed from ca. $90 \mathrm{Ma}$ onward because of subduction-related downwarping of Wrangellia (Dickinson 1976; Muller 1977; England 1990; England and Calon 1991; Massey 1992) or, altematively, in a transform or obliquely convergent margin setting (Umhoefer 1987). This extension predates the development of the large Cowichan fold-thrust system, which is developed within the Late Cretaceous Nanairno Group sediments. We correlate $\mathrm{D}_{4}$ at Myra Falls with the formation of the Nanaimo Basin.

In southem Vancouver Island, the Cretaceous to late Eocene deformation produced the major northeast-dipping tbrust faults that dominate the structural fabric of southem Vancouver Island and form the Cowichan fold and thrust belt (England and Calon 1991, Massey 1992, Yorath et al. 1985). The northeast-dipping tbrust faults have been mapped as far north as Campbell River along the east coast (e.g., England and Calon 1991). However, this is the first recognition of Eocene thrusting in the Buttle Lake Uplift. The $D_{S}$ faults are the dominant brittle structures at Myra Falls, with top-to-thewest-southwest displacement on shallow northeast-dipping thrust faults and sinistral displacement on steep west- to west-northwest-oriented strike-slip faults. The $D_{S}$ faults are gouge-rich, wavy, anastomosing structures with well-developed cleavage zones. Offsets on these faults range from several metres to several hundred metres and numerous large westto west-northwest-striking faults with apparent sinistral offset have been mapped in Strathcona Provincial Park by the Geological Survey of Canada. Several of these extend through Myra Falls VHMS camp (Fig. 3) and are correlated with the $D_{S}$ structures. The amount of shortening in the Cowichan fold and thrust bell has been shown to decrease markedly from south to north, with little evidence of shortening in the Nanaimo Group sediments north of Port Albemi (England and Calon 1991; Cathyl-Bickford and Hoffman 1998; Johnston and Acton 2003). The results of this study suggest the Eocene thrust province extends further north than previously observed. This is consistent with the suggested extension of the Cowichan fold and thrust belt as far north as Campbell River (Fig. 2 of England and Calon 1991) but con- trasts with the termination of these faults on the east coast north of Parksville (Cathyl-Bickford and Hoffinan 1998). The conclusion here is that the Eocene tbrust event is stronger and persists further to the north along central Vancouver Island than previously recognized.

Tertiary to Recent tbrust and strike-slip faulting has continued throughout the island as a result of continued northwest motion of the Pacific plate relative to the North American plate (Gabrielse 1991). Post-Eocene faulting in southem Vancouver Island is indicated by sinistral offset of the large northwest-striking Eocene faults along northeast-striking vertical faults (Massey 1992; Yorath et al. 1999). Northeast-striking faults of Miocene age are also reported by Joumeay and Csontos (1989) in the southem coast belt. At Myra Falls, some steep gouge-rich $D_{s}$ faults crosscut shallow-dipping northwest-striking $D_{S}$ thrust faults and may be related to a post-Eocene episode of brittle deformation. The effect of these structures is minor. We have grouped them with the $D_{S}$ event in our analysis and conclude that the post Eocene faulting is largely constrained to southem Vancouver Island. There is evidence of extension in the Port Albemi area associated with formation of the southem Vancouver Island orochne (Johnston and Acton 2003).

In northern Vancouver Island, the most recent phase of deformation is defined by minor northeast-striking normal faults (Nixon et al. 1994, 1995). These faults are the result of northwest to north-northwest-directed extension during the opening of the Queen Charlotte Basin (Riddihough and Hyndman 1991) and postdate the deposition of the Upper Cretaceous Nanaimo Group sediments. No late extensional structures were observed at Myra Falls suggesting this phase of deformation did not propagate into central Vancouver Island.

\section{Conclusions}

Five deformation events have been identified at Myra Falls VHMS camp, with early ductile deformation followed by several distinct episodes ofbrittle deformation (Fig. 11). The brittle events are distinguished by differences in the morphology, kinematics, and geometry of the faults and their crosscutting relations. The timing of deformation is determined by correlation with regional studies in northem, southem, and southcentral Vancouver Island.

(1) Northeast-southwest shortening during the pre-Permian $\mathrm{D}_{1}$ event produced northwest-trending upright asymmetric folds and a variably developed axial planar cleavage with subhorizontal lineations. This folding took place prior to the collision of Wrangellia with North America.

(2) A second ductile phase of deformation $\left(D_{z}\right)$ is marked by the development of localized $D_{z}$ shear zones slightly oblique to SI' This deformation records the collision of Wrangellia and North America (early to mid Jurassic) with northeast-southwest shortening and formation of the large northwest-trending uplifts throughout Vancouver Island by reactivation of Palaeozoic folds.

(3) Northeast-southwest compression during $\mathrm{D}_{3}$ at Myra Falls resulted in the !wo stage evolution of steep planar strikeslip faults $\left(\mathrm{D}_{3 \mathrm{a}}\right)$ and minor bedding-parallel thrusts $\left(\mathrm{D}_{3 \mathrm{~b}}\right)$. The strike-slip faults form a conjugate set of north-striking 
dextral faults and east-striking sinistral faults. A similar array of strike-slip faults and bedding-parallel thrusts described in northem Vancouver Island by Nixon et al. (1994) are mid to Late Cretaceous in age.

(4) North-south extension during $\mathrm{D}_{4}$ produced an array of steep north- and east-striking planar normal faults with steep calcite slickenfibres. These faults consistently crosscut the $\mathrm{D}_{3}$ faults and are most likely related to formation of the Nanaimo Basin during the Late Cretaceous.

(5) The normal faults are consistently offset by large $D_{S}$ faults, which have a markedly different morphology to earlier fault sets, as they are gouge-rich, wavy, anastomosing structures with well-developed cleavage zones. Northwest-striking, shallow northeast-dipping $\mathrm{D}_{\mathrm{S}}$ thrust faults displaya top-to-the-west and southwest displacement, with sinistral offset on west- to west-northwest-oriented steep strike-slip faults. These structures are correlated with large Eocene thrust faults in southem Vancouver Island, and are associated with deformation during collision and accretion of the Pacific Rim and Crescent Terranes along the southwestem margin of Vancouver Island.

Structural data from Myra Falls in central Vancouver Island provides an important key for the correlation of deformation events between the north and south of the island.

\section{Acknowledgements}

This work was carried out as part of a Ph.D. study at Myra Falls. We would especially like to thank Boliden-Westrnin Ud. for funding the project and the staff at Myra Falls for their help and numerous geological discussions. We also thank S. Johnston and an anonymous reviewer for their thorough reviews that greatly improved the paper.

\section{References}

Barrett, TJ., and Sherlock, R.L. 1996. Vokanic stratigraphy, lithogeochemistry, and seafloor setting of the H-W massive sulfide deposit, Myra Falls, Vancouver Island, British Columbia. Exploration and Mining Geology, 5: 421--458.

Brandon, M.T, Orchard, MJ., Parrish, R.R., Sutherland Brown, A., and Yorath, CJ. 1986. Fossil ages and isotopic dates from the Paleozoic Sicker Group and associated intrusive rocks, Vancouver Island, British Columbia. In Current research, part A. Geological Survey of Canada, Paper 86-1 A, pp. 683-696.

Browne, P.R.L. 1978. Hydrothermal alteration in active geothermal fields. Annual Review Earth Planet Science Letters, 6: 229-250.

Cathyl-Bickford, C.G., and Hoffinan, G. 1998. Geological maps of the Nanaimo and Comox Coal Fields. British Columbia Ministry of Energy, Mines and Petroleum Resources, Victoria, B.C.

Dawson, K.M., Panteleyev, A., Sutherland Brown, A., and Woodsworth, GJ. 1991. Regional metallogeny. In Geology of the Cordilleran Orogen in Canada. Edited by H. Gabrielse and CJ. Yorath. Geological Survey of Canada, Ottawa, Ont., Geology of Canada, No. 4, Vol. G-2, Chap. 19, pp. 707-768.

Dickinson, W.R. 1976. Sedimentary basins developed during evolution of Mesozoic-Cenozoic arc-trench system in western North America. Canadian Journal of Earth Sciences, 13: 1268-1287.

England, T.DJ. 1990. Late Cretaceous to Paleogene evolution of the Georgia Basin, southwestern British Columbia. Ph.D. thesis,
Memorial University of Newfoundland, St. John's, Newfoundland, p. 481.

England, TDJ., and Calon, TJ. 1991. The Cowichan fold and thrust system, Vancouver Island, southwestern British Columbia. Geological Society of America Bulletin, 103: 336-362.

Etchecopar, A., Vasseur, G., and Daignieres, M. 1981. An inverse problem in microtectonics for the determination of stress tensors from fault striation analysis. Journal of Structural Geology, 3(1): 51-65.

Gabrielse, H. 1991. Structural styles. In Geology of the Cordilleran Orogen in Canada. Edited by H.Gabrielse and C.l. Yorath. Geological Survey of Canada, Ottawa, Ont., Geology of Canada, No. 4, Vol. G-2, Chap. 17, pp. 571-675.

Gabrielse, H., and Yorath, CJ. 1991. Tectonic synthesis. In Geology of the Cordilleran Orogen in Canada. Edited by H. Gabrielse and CJ. Yorath. Geological Survey of Canada, Ottawa, Ont., Geology of Canada, No. 4, Vol. G-2, Chap. 18, pp. 677-705.

Gordey, S.P., Geldsetzer, RHJ., Morrow, D.W., Bamber, E.W., Henderson, C.M., Richards, B.C., McGugan, A., Gibson, D.W., and Poulton, TP. 1991. Upper Devonian to Middle Jurassic assemblages. In Geology of tbe Cordilleran Orogen in Canada. Edited by H. Gabrielse and c.l. Yorath. Geological Survey of Canada, Ottawa, Ont., Geology of Canada, No. 4, Vol. G-2, Chap. 8, pp. 219-327.

Greenwood, HJ., Woodsworth, GJ., Read, P.B., Ghent, E.D., and Evenchick, C.A. 1991. Metamorphism. In Geology of the Cordilleran Orogen in Canada. Edited by H. Gabrielse and CJ. Yorath. Geological Survey of Canada, Ottawa, Ont., GeoJogy of Canada, No. 4, Vol. G-2, Chap. 16, pp. 533-570.

Gunning, H.C. 1931. Buttle Lake Map Area, Vancouver Island, BC. In Summary report, 1930, part A. Geological Survey of Canada, pp. 56A-78A.

Homberg, C., Lacombe, 0., Angelier, J., and Bergerat, F. 1999. New constraints for indentation mechanisms in arcuate belts from the Jura Mountains, France. Geology, 27: 827-830.

Hyndman, R.D., Yorath, CJ., Clowes, R.M., and Davis, E.E. 1990. The northem Cascadia subduction zone at Vancouver Island seismic structure and tectonic history. Canadian Journal of Earth Sciences, 27: 313-329.

Jeffery, WG. 1967. Buttle Lake. British Columbia Ministry of Energy, Mines and Petroleum Resources, Geological Branch, Open File Report, June 1967, pp. 21-67.

Johnston, S.T 2001. The Great Alaskan terrane wreck: reconciliation of paleomagnetic and geological data in the northern Cordillera. Earth and Planetary Science Letters, 193: 259-272.

Johnston, S.T., and Acton, S. 2003. The Eocene Southern Vancouver !sland orocline a response to seamount accretion and the cause of fold-and-thrust belt and extensional basin formation. Tectonophysics,365: 165- 183.

Jones, S.A. 2002. Geology and geochemistry of the 'Caprocks' above VHMS deposits at Myra Falls, Vancouver Island, B.C., Canada. Unpublished Ph.D thesis, University of Tasmania, Hobart, Tasmania, Austra[ia, 511 p.

Jones, S.A., and Berry, R. 200 I. Recognition of early growth structures after multiple deformation episodes at Myra Falls VHMS camp, Vancouver !sland, BC, Canada. In Specialist Group in Tectonics and Structural Geology (SGTSG) conference, 200 I: A structural odyssey, Geological Society of Australia, Tasmania, Australia, Feb. 2001. Centre for Ore Deposit Research, University of Tasmania, Hobart, Australia, Special Publication 64, Abstract Vol., pp. 101-102.

Jones, S.A., GemmelI, J.B., Davidson, GJ., and Boliden-Westmin geological staff. 2000. Geological and geochemical characteristics 
of siliceous 'cap rocks', Myra Falls VHMS camp, Vancouver Island, BC, Canada. In Volcanic environments aod massive sulfides conference. Centre for Ore Deposit Research, University of Tasmania, Hobart, Australia, Special Publication 3, Abstract Vol., pp. 105-106.

Journeay, J.M., and Csontos, L. 1989. Preliminary report on the structural setting along the Southeast Flank of the Coast Belt, British Columbia. In Current research, part E. Geological Survey ofCanada, Paper 89-IE, pp. 177-187.

Juras, S.1. 1987. Geology of the polymetallic volcanogenic Buttle Lake camp, with emphasis on the Price hillside, Central Vancouver Island, British Columbia, Canada. Unpublished Ph.D thesis, The University of British Columbia, Vancouver, B.C., 278 p.

Juras, S.G., and Pearson, CA. 1990a. The Buttle Lake Camp, Central Vancouver Island, BC. In Proceedings of the 8th IAGOD (International Association on the Genesis of Ore Deposits) Symposium Field Trip Guidebook: Geology and Regional Setting of Major Mineral Deposits in British Columbia. Geological Survey of Canada, Open File 2167, pp. 145-161.

Juras, S.G., and Pearson, CA 1990b. Mineral deposits of the southern Canadian Cordillera. Guidebook for Field Trip B2. Geological Association of Canada - Mineral Association of Canada Joint Meeting, Vancouver, B.C., 1990, pp. 1-21.

Liesa, c.L., and Lisle, R.L. 2004. Reliability of methods to separate stress tensors from heterogeneous fault-slip data. Journal of Structural Geology, 26: 559-572.

Mackie, D.C. 2002. An integrated structural and hydrogeologic investigation of the fracture system in the Upper Cretaceous Nanaimo Group, southern Gulf Islands, British Columbia. Simon Fraser University, Burnaby, B.C., Canada, Monograph, 358 p.

Massey, N.W.D. 1992. Geology and mineral resources of the Duncan sheet, Vancouver Island. Geological Survey of Canada, Report 92B/13, 57 p.

Monger, J.WH., Price, R.A., and Tempelman-Kluit, D.1. 1982. Tectonic accretion and the origin of the two major metamorphic and plutonic welts in the Canadian Cordillera. Geology, 10: 70--75.

Monger, J.WH., Clowes, R.M., Price, R.A., Riddihough, R.P., and Woodsworth, G.1. 1985. Continent-ocean transect B2: Juan de Fuca plate to Alberta Plains; explanatory pamphlet. Geological Society of America, Decade ofNorth American Geology, 21 p.

Muller, J.E. 1977. Evolution of the Pacific Margin, Vancouver Island, and adjacent regions. Canadian Journal of Earth Sciences, 14: 2062-2085.

Muller, 1.E. 1980. The Paleozoic Sicker Group of Vancouver Island, British Columbia. Geological Survey of Canada, Paper 79-30, $22 \mathrm{p}$.

Nixon, G.T., Hammack, 1.L., Koyanagi, Y.M., Payie, G.1., Panteleyev, A., Massey, N.WD., and Hamilton, 1.Y. 1994. Preliminary geology of the Quatsino - Port McNeill map areas, northern Vancouver
Island (92U12, II). In Geological fieldwork 1993. Geological Survey of Canada, Paper 1994-1, pp. 63-85.

Nixon, G.T., Hammack, J.L., Payie, G.1., and Snyder, L.D. 1995. Quatsino - San Josef map area, northern Vancouver Island. Geological overview (92UI2W, 102U8, 9). In Geological fieldwork 1994. Geological Survey of Canada, Paper 1995-1, pp. 9-21.

Pearson, C.A. 1993. Mining zinc-rich massive sulfide deposits on Yancouver Island, British Columbia. In Proceedings Volume, International Symposium - World Zinc 93, Hobart, Australia. pp. 75-84.

Petit, J.P. 1987. Criteria for the sense of movement on fault surfaces in brittle rocks. Journal of Structural Geology, 9: 597-608.

Ramsay, J.G., and Huber, J.G. 1987. The techniques of modem structural geology. Vol. 2: Folds and fractures. Academic Press, Harcourt Brace Jovanovich Publishers, London, UK., 700 p.

Riddihough, R.R., and Hyodman, R.D. 1991. Modem plate tectonic regime of the continental margin of western Canada. In Geology of the Cordilleran Orogen in Canada. Edited by $\mathrm{H}$. GabrieJse and C.1. Yorath. Geological Survey of Canada, Ottawa, Ont., Geology of Canada, No. 4, VoL G-2, Chap. 13, pp. 435--455.

Robinson, M., Godwin, C.L, and Stanley, C.R. 1996. Geology, Iithogeocbemisty, and alteration of the Battle volcanogenic massive sulfide zone, Buttle Lake Mining Camp, Vancouver Island, British Columbia. Economic Geology, 91: 527-548.

Sinclair, B. 2000. Geology and genesis of tbe Battle Zone VHMS deposits, Myra Falls district, British Columbia, Canada. Unpublished Ph.D. thesis, University of Tasmania, Hobart, Tasmania, Australia, $321 \mathrm{p}$.

Sinclair, B.1., Gemmeli, 1.B., and Berry, R.F. 2000. Formation of the Battle mine massive sulfide deposits, Myra Falls, VHMS district, Vaocouver 1sland, B.C., Canada. In Volcanic environments and massive sulfide deposits. Centre for Ore Deposit Research, University of Tasmania, Hobart, Australia, Special Publication 3, Abstract VoL, pp. 195-196.

Umhoefer, P.J. 1987. Northward translation of the "Baja British Columbia" along the Late Cretaceous to Paleocene margin of western North America. Tectonics, 6: 377-394.

Walker, R.R. 1985. Westrnin resources' massive sulphide deposits, Vancouver Island; trip 1. In Field guide to geology and mineral deposits in the southern Canadian cordillera. Edited by D. Tempelmao-KJuit. Geological Society of America, Cordilleran Section Meeting, May 1985, Yancouver, B.C., pp. 1.1-1.3.

Yorath, C.1., and Nasmith, H.W 1995. The geology of Southern Vaocouver Island - a field guide. Orca Book Publishers, Victoria, B.C.

Yorath, C.1., Sutherland Brown, A., and Massey, N.WD. 1999. Lithoprobe, southern Vaocouver lsland, British Columbia: Geology. Geological Survey of Canada, Bulletin 498, 145 p. 